\title{
AS PAISAGENS PERCEBIDAS NO TURISMO EM ÁREAS RURAIS: UM ESTUDO DOS DIFERENTES OLHARES SOBRE A PERCEPÇÃO DE PARAÍSO.
}

\author{
Icléa Viana Pimenta \\ ORIENTADORA: PROF ${ }^{\mathrm{a}}$. (M.SC) SANDRA VIVACQUA VON \\ TIESENHAUSEN
}

\begin{abstract}
Monografia apresentada ao Centro de Excelência em Turismo (CET) da Universidade de Brasília (UnB) como requisito parcial para a obtenção do certificado de especialista em Turismo e Hospitalidade.
\end{abstract}


UNIVERSIDADE DE BRASÍLIA (UNB)

Centro de Excelência em Turismo (CET)

Curso de Especialização em Turismo e Hospitalidade

\section{AS PAISAGENS PERCEBIDAS NO TURISMO EM ÁREAS RURAIS: UM ESTUDO DOS DIFERENTES OLHARES SOBRE A PERCEPÇÃO DE PARAÍSO.}

Icléa Viana Pimenta

Banca Examinadora

PROF $^{\mathrm{a}}$. (MSc) Sandra Vivacqua von Tiesenhausen

Brasília, Distrito Federal, 02 de fevereiro de 2004. 
FICHA CATALOGRÁFICA

PIMENTA, ICLEA VIANA.

AS PAISAGENS PERCEBIDAS NO TURISMO EM ÁREAS RURAIS: UM ESTUDO DOS DIFERENTES OLHARES SOBRE A PERCEPÇÃO DE PARAÍSO.I Icléa Viana Pimenta

63 p., 210x297mm (CET/UnB, Especialização, Centro de Excelência em Turismo, 2004).

Monografia de Especialização - Centro de Excelência em Turismo - Universidade de Brasília, 2004.

Área: Turismo e Hospitalidade

Orientadora: Prof ${ }^{a}$. MSc. Sandra Vivacqua von Tiesenhausen

Palavras-chaves 1. Turismo, 2. Paisagem, 3. Cerrado, 4. Paraíso. 
FOLHA DE APROVAÇÃO

Profa. M. Sc. Sandra Vivacqua von Tiesenhausen - Orientadora 
Dedico esta monografia a meu companheiro Leonel Leonardo Delgado Morales, pelo amor, carinho, incentivo constantes e ao meu anjinho Andrei Mateus Viana Delgado Morales, ao meu bonequinho Alexei Leonardo Viana Delgado Morales e ao agora, universitário, Alessandro Billy Viana Pimenta da Silva, meus filhos, que são o que encorajam a batalhar pela vida todos os dias. 


\section{AGRADECIMENTOS}

Em especial, a todos os funcionários do Centro de Excelência em Turismo, sobretudo ao Pedro que procurou nos atender sempre com muita paciência .

Aos colegas do curso de especialização em Turismo e Hospitalidade, que, quando solicitados, atenderam-me com toda atenção e carinho, em especial ao meu amigo Paulo Henrique pelas horas de atenção dedicadas.

À professora Sandra Vivacqua von Tiesenhausen, pelas palavras certas nas minhas horas incertas. 
Eu semeei meus sonhos onde você está pisando agora, pise devagarinho pois você está pisando nos meus sonhos.

Paulo Coelho 


\section{RESUMO}

Neste trabalho apresenta-se um estudo dos diferentes olhares sobre a paisagem, como as pessoas constroem seu ideal de paraíso e a relação que os aspectos social, psicológico, cultural têm nesta construção. Analisando-as a partir das imagens do cerrado que é o contexto em que essas imagens estão inseridas.

Foram realizadas uma recopilação de depoimentos e imagens de pessoas relacionadas com atividades turisticas em dois empreendimentos na região cerrana do Distrito Federal. 


\section{ABSTRACT}

In this paper, we intend to show a study of diffent lookings about the scenery, as the people build their ideal of the paradise and the relation which the social aspects, psychology and the cultural have in this construction. Analyzing them from the images from the scrub, what is the context that these images are inserted.

A king of compilation of the statements and the people's images related with turistic activities in two undertakings in the cerrana region of the Federal District, Brasilia. 


\section{SUMÁRIO}

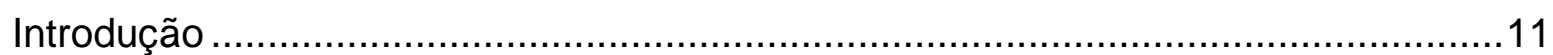

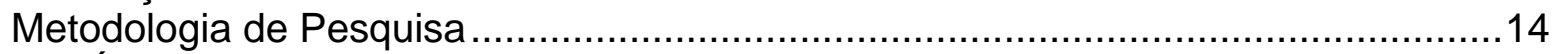

CAPÍTULO I: O Porquê da Busca da Paisagem Rural........................................14

1.1 A Construção da Paisagem Natural ................................................14

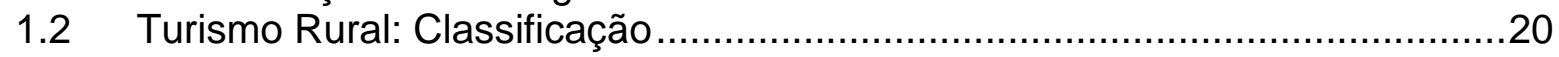

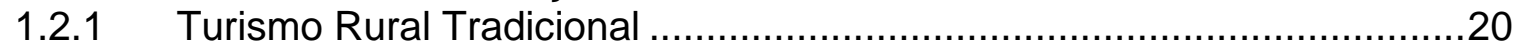

1.2.2 Turismo Rural Contemporãneo ..................................................... 21

CAPÍTULO II: Carcterizando as Paisagens do Cerrado.......................................22

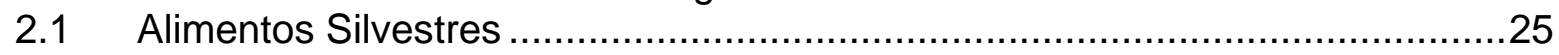

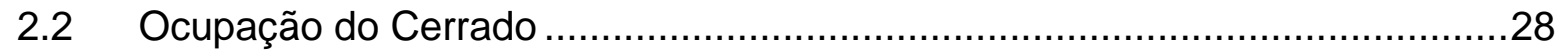

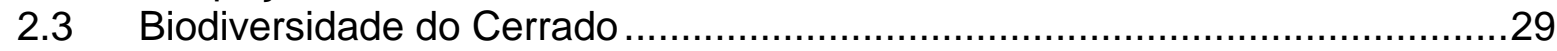

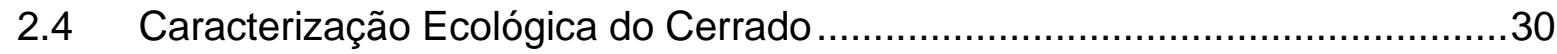

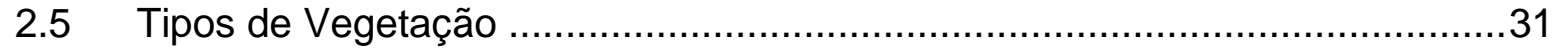

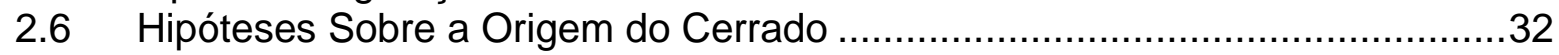

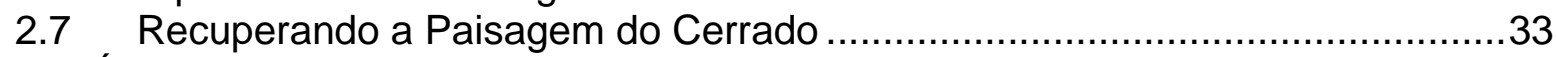

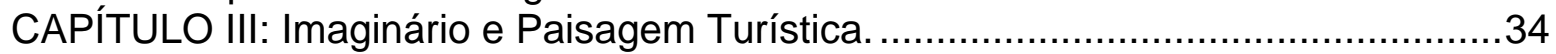

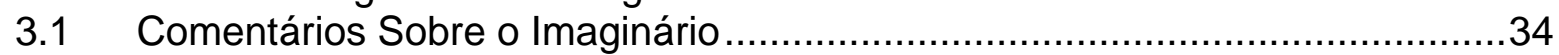

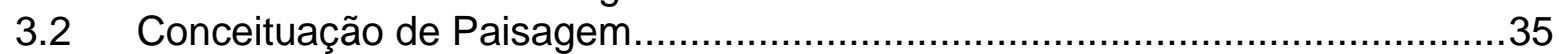

CAPÍTULO IV: A Construção de Paraíso ......................................................... 38

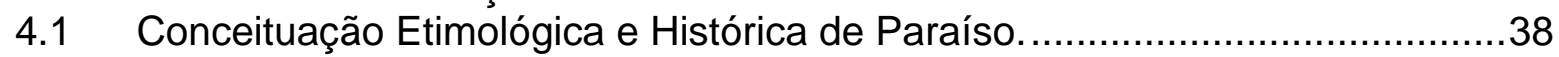

4.2 O Mito Brasileiro de Paraíso .....................................................................40

4.3 O Paraíso Relacionado com as Imagens do Cerrado .................................42

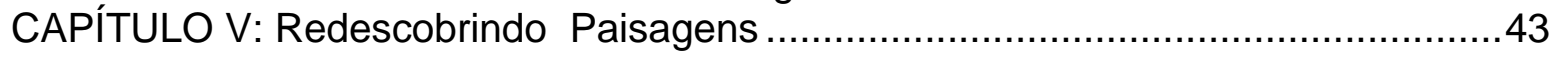

5.1 Paraíso Natural versus Paraíso Construído .............................................43

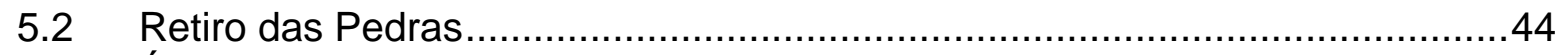

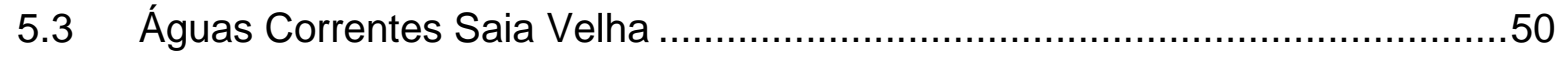

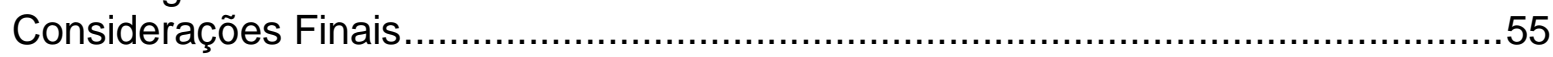

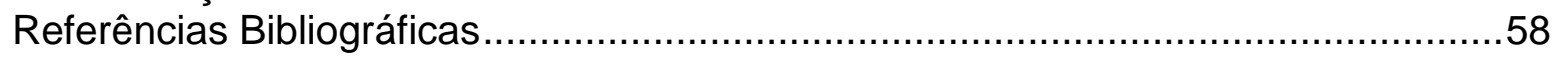

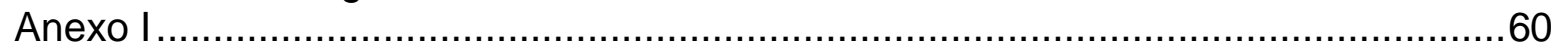

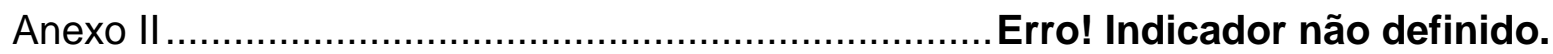




\section{INTRODUÇÃO}

Para tratar do tema, começarei fazendo a descrição da minha paisagem.

Sou professora com experiência profissional em educação no ensino Fundamental, Médio e Superior, leciono língua portuguesa.Tanto a palavra quanto a imagem me seduzem e tentar aliar as duas com percepção e emoção é o que vai ditar o curso deste trabalho.

Residia até o ano de 2002 no Estado do Rio de Janeiro onde, nos feriados prolongados e férias saía como (quase) todo carioca para as praias do litoral, tanto da Costa Verde quanto da região dos Lagos. Pegava horas de longos engarrafamentos, calor, estresse. Ao chegar ao local tinha de disputar um espaço na areia com centenas de pessoas. Ao final da jornada estava mais cansada que quando saía de casa, tudo em nome da busca do paraíso, paraíso que para mim, neste momento, tinha nome que se traduzia nas areias de Angra dos Reis, Muriqui, Ibicuí, Ilha Grande ou ainda na região serrana de Itatiaia ou Penedo. Enquanto escrevo estas linhas, as imagens vão se sucedendo uma a uma em minha mente e retorno mesmo que por momentos a esses paraísos. Nosso imaginário é desterritorializado. Ou melhor, o território é aqui ou logo ali, tanto faz porque para a imaginação o longe pode ser perto, o espaço é ilimitado e o paraíso inimaginável. Segundo Collot (1990, p.27) a paisagem se define como "espaço ao alcance do olhar", mas também a disposição do corpo; e esta se reveste de significados ligados a todos os comportamentos possíveis do sujeito. O ver amplia-se para o poder.

Nenhum propagandista conseguiria descrever com imagens e palavras o paraíso de cada um de nós, quando encontramos, porém, numa imagem sugerida algo que nos seduz, tentamos alcançar essas imagens materializadas através daquilo que se convencionou chamar turismo e nos deslocamos de nossas casas até nosso destino "por um período de tempo consecutivo inferior a um ano com fim de ócio, por negócio e outros motivos" (OMS- 1991) .

Hoje, vivo na região do Distrito Federal e logo que aqui cheguei, me apaixonei pelo cerrado; a imagem das árvores tortuosas me prenderam a atenção e queria 
saber como se chamavam, para que serviam, queria rimar cerrado com poesia. Admitida no curso de Turismo do CET, conversamos sobre percepção, imagem cerrado, imaginário, paisagem, paraíso. E pensei por que não unir todas essas palavras neste trabalho e dessa forma por que não falar dessa imagem que ficou tão forte em mim a PAISAGEM RURAL, A PAISAGEM DO CERRADO. Afinal, segundo Collot (1990) "A busca ou a escolha de paisagens privilegiadas é uma forma da procura de si mesmo", e eu me encontro nas paisagens do cerrado. A modo de ilustração, observe o seguinte trecho:

Associam-se também a paisagem valores afetivos que serão diferentes para cada indivíduo e estes valores se associam a fatores psicológicos. Cada um de nós sempre guarda na memória a imagem de uma paisagem marcante, que muitas vezes tem um significado afetivo. Sobretudo os indivíduos que se mudaram de uma região para outra, sempre guardam na mamória imagens da paisagem de sua região.

(Neves, 1992, p. 109)

Este trabalho monográfico pretende discutir um pouco o que falam os autores sobre turismo rural e turismo em áreas rurais abordando os diferentes tipos de paisasem encontradas no espaço rural, mostrar algumas características do cerrado e fazer uma análise das imagens captadas em trabalho de campo que visa mostrar a importância da construção da paisagem para cada pessoa.

Para Ézia Socorro Neves (1992. p.110), pela história da humanidade sempre ter estado associada à da natureza, já que o homem faz parte dela. As atitudes do homem para com a natureza/paisagem têm variado no tempo, distinguindo-se três fases:

a) A natureza como sinônimo de Deus, quando devido ao desconhecimento, era temida pelo homem;

b) A natureza encarada como meio. O homem aceita os condicionantes naturais como fatores limitantes, aprende então a usá-la;

c) Os avanços tecnólogicos conquistados pela sociedade não se intimidam frente a fatores condionantes ou limitantes da natureza. 
Por isso, podemos afirmar que hoje o homem busca uma forma pacífica de lidar com a natureza, sem domá-la ou dominá-la mas interagindo com ela e buscando novas formas de admirá-la sem gastá-la e desgastá-la, porém preservando-a.

Em vista do apresentado, a referida dissertação tem como objetivos:

a) Discutir a importância do Turismo no espaço rural na construção da imagem de paraíso pessoal, partindo de fotografias captadas por turistas e trabalhadores de empreendimentos rurais;

b) Investigar como esses elementos interagem entre si e como agem na formação da percepção de paisagem.

Dessa forma, este trabalho será desenvolvido em cinco capítulos, sendo distribuidos da seguinte forma:

No primeiro capítulo, serão abordados os aspectos da paisagem rural, a maneira como ele é percebido, o valor turístico das paisagens humanizadas e finalmente a classificação do turismo rural. No segundo capítulo, será realizada uma descrição da paisagem do cerrado, abordando espécies arbóreas, a ocupação do cerrado, assim como a sua biodiversidade, a abordagem sobre a paisagem turística e imaginário será tratado no terceiro capítulo. No quarto capítulo se fará uma recopilação de definições do termo paraíso e do paraíso com relação as imagens do cerrado. Enfim, no quinto capítulo apresenta-se uma análise dos materiais coletados por meio de entrevistas, depoimentos e imagens realizadas junto aos profissionais que trabalham nos estabelecimentos que exploram o turismo rural e dos turistas que procuram, nestes locais, encontrar seu paraíso sonhado. 


\section{METODOLOGIA DE PESQUISA}

O processo de pesquisa dar-se-á na aplicação da revisão bibliográfica dos conceitos sobre turismo rural e turismo em áreas rurais através de autores como Mary Mércia G. Salles; Silva, Vilarinho e Dale e Adyr Balatreri Rodrigues.

Os conceitos de imaginário, paisagem, paraíso serão repassados através de autores como Bittencourt, Ézia Socorro Neves, Paulo dos Santos Pires, Marcello Martinelli, Michel Collot, Sabáh Aoun, entre outros.

Esse referencial teórico servirá de base para o desenvolvimento desse trabalho de pesquisa que acontecerá da seguinte forma:

a) Coleta de depoimentos e de imagens sugeridas pelos turistas, e funcionários de dois empreendimentos turísticos do Distrito Federal;

b) Análise das imagens associadas aos textos presentes.

\section{CAPÍTULO I: O PORQUÊ DA BUSCA DA PAISAGEM RURAL}

\subsection{A Construção da Paisagem Natural}

A vida estressante da cidade faz com que as pessoas busquem cada vez mais o contato com o natural. As cidades devido ao processo de globalização, o desenvolvimento de novas tecnologias e aos avançados dos processos construtivos estão muito parecidas e apresentam o mesmo nível de desgaste e miserablilidade. $\mathrm{O}$ processo de urbanização faz com que muitas cidades percam sua identidade paisagístisca.

Observe essa passagem de a Alma do lugar:

Hoje se assiste a uma repetição da relação arquitetura-urbanismo em muitos centros urbanos e dinâmicos do Brasil. Com o desenvolvimento da indústria brasileira da construção, propagou-se o uso dos mesmos materiais e, muitas vezes, das mesmas tecnologias. Esse fato se faz acompanhar de certos estilos de gestão municipal, cheios de vício de 
copiar ou da vergonha pelo velho. Repete-se, por quase todas as partes, a adoção dos mesmos tipos de equipamentos.

(Yázigi, 2001, p.15)

Em comparação ao nível de relação de convivência existente entre cidade e campo, o mesmo autor afirma:

No Brasil, cujo padrão de metropolização não conheceu o capitalismo concorrencial, comumente, uma pequena cidade assume ares de fragmento de cidade grande. Pior ainda, fica sem as qualidades do pequeno e com muitas desvantagens do grande.

(Yázigi, 2001, p.15)

A paisagem que vemos nas novelas globais é bem diferente da que estamos acostumados a ver nos jornais escritos e televisivos ou ainda da que está ao nosso redor. Somos massacrados por imagens de guerra, mortes, fome. Como não buscar se alojar ou esconder no conforto do espaço rural, fugindo das desgastantes cenas do nosso dia-a-dia. Vivendo apertados em apartamentos e casa minúsculas onde a possibilidade de ter um jardim, muitas vezes limita-se ao ato de pendurar uma bela gravura na parede ou cuidar de alguns vasinhos de plantas.

Yázigi (2001), assim descreve esse estado de miséria que assola nossa paisagem:

São essas condições sociais, usos ou desusos tecnólogicos e de normatizações por códigos vampiros, que fazem a urbanização reproduzir os mesmos esquemas em quase todas as partes, nivelando os aspectos morfológicos em detrimento de possíveis afirmações positivas de identidades espaciais, Ou, dito de outra forma, a par de uma renovação que não conservou o antigo, assiste-se a uma progressiva visibilidade da miséria (a não ser confundida com pobreza) esta sim, caracterizando a identidade de todos os lugares, tal o vulto que vem tomando. São bairros inteiros de contruçôes feitas de refugos, ou com blocos de cimento aparente, sem qualquer acabamento. Carente de qualquer conhecimento arquitetônico mais elaborado, a massa de autoconstrutores não só materializa soluções equivocadas, como desguarnecidas de estéticos mínimos: a combinação de formas, proporções e materiais; as superfícies emplacadas no liso, onde o adorno ou acabamentos parecem formas de delírio. Além do mais 
espremidos em lotes de dimenções inaceitáveis, tanto do ponto de vista sanitário como no de privacidade, as unidades de vizinhança se vêem entulhadas, raramente dispondo de um jardim ou quintal com árvores ou outras amenidades,

(Yázigi, 2001, p.14)

Esse conflito de paisagens faz com que busquemos soluções, uma outra maneira de enxergar a realidade, os japoneses até já inventaram a máquina de sonhar, numa tentativa de nos induzir à novas paisagens, novos paraísos.

Yázigi (2001, p.13) afirma que o estudo dos lugares no Brasil costuma começar erroneamente pela fundação das cidades pois a história da colonização começou na área rural. E o campo é visto como atrasado e a cidade como progresso. Nancy Alessio Magalhães (1998) em seu artigo "A percepção do rural e do urbano na construção da memória social das cidades", mostra-nos como os processos de simplificação e oposição das relações entre cidade e campo são utilizados para silenciar as interconexões existentes e que ao serem explicitadas desnudam os conflitos que permanecem não resolvidos até hoje.

Por isso é que a imagem comum do campo é a que o identifica com o passado (rural), perdido e tranquilo, embora atrasado e limitado. E, uma imagem comum da cidade é a que a identifica com o futuro, urbano a conquistar, intranquilo, mas moderno, com promessas de prosperidade e progresso.

(Magalhães,1998, p.25)

A propaganda publicitária, hoje, é muito eficiente na manipulação do imaginário do indivíduo e muitas vezes esse imaginário nos remete à busca de ambientes naturais, fazendo crescer, assim, a demanda pelo Turismo em áreas rurais.

E segundo Ruschmann (2001) os turistas que buscam as áreas rurais "são pessoas descontentes com as estruturas clássicas, situadas no mar ou na montanha. Eles buscam aspectos simples e autênticos, característicos do dia-a-dia do meio 
agrícola, sem contudo abdicar de um conforto razoável comparado àquele do cotidiano"

A valorização da paisagem rural perpassa pela valorização do desejo de ver realizado o sonho de estar próximo ao paraíso, ao Éden. imagem, esta, tão valorizada pelos folhetos turísticos e que faz com que qualquer pessoa sonhe em estar próximo a ele, fugindo do estresse das grandes cidades.

Para ratificar tal afirmação, temos:

Tudo parece ter sido meticulosamente arquitetado com séculos de antecipação. Cria-se a fábrica, cria-se a metrópole, cria-se o estresse urbano, cria-se a necessidade do retorno à natureza. Onde não há natureza, ela é fabricada.

(Rodrigues, 1997, p.30).

Deve-se observar a esta altura da discussão, o cuidado ao tratar a questão do turismo praticado em áreas rurais e o turismo rural propriamente dito; Isto devido, principalmente, aos diferentes enfoques em relação a definição do conceito, encontrados na literatura, assim é importante citar a abordagem feita por Silva, Vilarinho e Dale (2001), que baseiam a análise, fundamentalmente, do ponto de vista do aproveitamento do espaço com atividades de mero lazer, pode-se citar os inúmeros clubes existentes, e aqueles que convidam o turista a participar das rotinas características do lugar, como é o caso de uma fazenda-hotel.

A paisagem por ser uma construção individual e pessoal, deve ser tratada a partir da percepção do ser humano. Pois só ele pode atribuir a essa imagem significados e valores.

Quanto mais desautomatizado for o olhar sobre a paissagem mais será carregado de lirismo, pois disso depende sua composição e interpretação. Por isso segundo Jordana (1992) a percepção individual da paisagem está condicionada a três fatores básicos, que são:

a) os fatores inerentes ao próprio indivíduo, estes têm relação com a forma de observar, a capacidade imaginativa; 
b) fatores educativos e culturais condicionantes, referidos à influência da sociedade e de seus padrões sobre o aprendizado cultural e estético do indivíduo;

c) fatores emotivos, afetivos e sensitivos, relacionados ao grau de familiaridade e o conhecimento do meio.

Embora a percepção seja gerada por um campo de impressões sensoriais deve-se ressaltar a importância da visão na captação dessas impressões proporcionadas pela paisagem, como afirma Bombim (in: Pires, 1987). A paisagem, a visibilidade, o observador e a interpretação são elementos básicos na percepção da paisagem.

Jordana (in: Pires, 1992) assinala que pela diversidade semântica sobre a idéia de paisagem, dependendo da área do conhecimento a que está relacionada, pode assumir a dimensão estética ou visual, relacionada a aspectos sensitivos e perceptivos; a dimensão cultural em que o homem pode atuar como agente modelador; e a dimensão ecológica na qual a paisagem resulta de um conjunto de inter-relações físicas e biológicas.

A paisagem pode ainda constituir-se de valores de qualidade e de fragilidade visual. Ignácio (in: Pires, 1994) "define a qualidade de uma paisagem como o grau de excelência de suas características visuais, constituindo no mérito para não ser alterada ou destruída."

A componente fragilidade visual da paisagem age no sentido oposto da componente capacidade da paisagem pois quanto maior a capacidade da paisagem absorver possíveis alterações sem perda da qualidade, menor será sua fragilidade.

Vários são os fatores que atúam na deterioração da paisagem natural, fragilizando-a: a agricultura, a urbanização, a indústria, o turismo. Observe o trecho:

A paisagem, não só de conteúdo natural, mas também dotada de vida humana, ganha, desta feita, grande destaque no mundo das imagens do turismo. Torna-se recurso. É vendida com forte dose de fantasia. Negocia-se o verde da floresta, o cume da montanha, o pôr-do-sol dourado, a praia ensolarada com o mar azul engastado pelos coquieros, a praça emoldurada por casas coloniais e sua majestosa 
igreja. Esse imaginário, quanto mais distante de nós, mais exótico se torna. Exerce maior encanto, mistério e estímulo. Cada cultura, no entanto, enaltece seu arquétipo.

(Martinelli, 2001, p.152)

Partindo de estudos realizados no sul do Brasil, Pires (2001) sugere duas variáveis na análise da paisagem rural a topografia referindo-se ao relevo de uma região e ao uso do solo representando os aspestos extensivo relacionada à paisagem natural; intensivo quando a paisagem começa a sofrer modificações; e diversificado que está relacionado a traços étnico-culturais. Por achar que esses elementos que caracterizam a paisagem podem ser aplicados não só no sul do Brasil, mas em todas as regiões do país, é que os referencio neste trabalho.

E a propósito desses elementos caracterizadores e diferenciadores presentes no espaço rural, Pires (2001) sugere duas sub-tipologias básicas, que são:

a) a paisagem campestre que está relacionada ao aspecto extensivo do espaço rural, constituindo-se de paisagens naturais;

b) a paisagem cultivada que está relacionada aos aspectos intensivo e diversificado do uso do solo.

Antes de realizar uma classificação de turismo rural, é pertinente apresentar algumas das definições que têm sido fornecidas na literatura revisada. Para Salles, (2003) o turismo rural, reconhecendo suas múltiplas variedades, é conceituado, segundo a EMBRATUR, (1994), como:

um turismo diferente, turismo interior, turismo doméstico, turismo integrado, turismo endógeno, alternativo, agroturismo, turimo verde. É o turismo do país, um turismo concebido por e com os habitantes desse país, um turismo que respeita a sua identidade, um turismo de zona rural em todas as suas formas. 
Outra conceituação pode ser observada na citação seguinte:

Atividade multidisciplinar que se realiza no meio ambiente, fora de áreas intensamente urbanizadas. Caracteriza-se por empresas turísticas de pequeno porte, que tem no uso da terra a atividade econômica predominante, voltada para práticas agrícolas e pecuárias.

(Silva, Vilarinho e Dale, 2000, p. 18-19)

É válido ressaltar que atualmente, como mencionado em Salles (2003), a definição apresentada acima é utilizada pela EMBRATUR e agentes que trabalham no setor.

\subsection{Turismo Rural: Classificação}

Como forma de esclarecimento, a seguir é apresentada uma classificação de turismo rural sugerida por Rodrigues (2001, p. 110-115):

\subsubsection{Turismo Rural Tradicional}

1) De origem agrícola - este tipo é comumente rotulado de fazenda-hotel, não se confundindo com hotel-fazenda, uma vez que esse rótulo designa o estabelecimento que já foi construído com o intuito de ser um meio de hospedagem.

2) De origem pecuarista - considerando equipamentos de hospedagem que se originaram pela pecuária tradicional, distinguem-se áreas onde a atividade de criação de gado funcionou como instrumento de apropriação do território durante a colonização.

3) De colonização européia - sua origem está relacionada à história da imigração européia no Brasil. Algumas fazendas apresentam instalações suntuosas cujos proprietários residem ou não na propriedade e cuja atividade agrária é ainda importante, sendo o turismo atividade complementar. 


\subsubsection{Turismo Rural Contemporãneo}

São equipamentos turísticos implantados a partir dos anos 70, caracterizando-se como uma modalidade de turismo alternativo ao modelo "sol e praia".

1) Hotéis-fazenda - Trata-se de hotéis localizados na zona rural, implantados deliberadamente para exploração desse turismo específico, valorizando a cultura rural, como o folclore, a gastronomia, as atividades, tais como cavalgadas, esporte rural dos mais apreciados.

2) Pousadas rurais - de menor porte e menos luxo procuram oferecer aos visitantes usufruir da vida no campo sem muita sofisticação.

3) Spas rurais - Podem ser enquadrados também na categoria turismo de saúde, constituíndo a versão moderna das antigas estações termais, hoje com fins estéticos, situando-se na zona rural com o intuito de oferecer aos pacientes-hóspedes o bucolismo da vida campestre, associando a ele muitas caminhadas, para queimar calorias e produzir o relaxamento necessário para suportar o corte drástico de calorias das dietas.

4) segunda residência campestre - geralmente localizados na área rural de municípios vizinhos de grandes centros urbanos.

5) Campings e acampamentos rurais - são importantes para hospedar jovens e famílias com crianças, demanda bastante significativa do turismo rural.

6) Turismo de caça e pesca - representado pelos ranchos de pesca e propriedades onde a caça é permitida por lei, pois os animais são criados para esse fim.

7) Turismo rural místico ou religioso - Alguns estabelecimentos estão ligados à religião, enquanto outros centros de vivência comunitária, vinculados à meditação e práticas místicas.

8) Turismo rural científico-pedagógico - principalmente voltados para a recepção de aluno médio e superior que estão abrindo suas portas para visitas e estadas associando turismo, lazer e ensino.

9) Turismo rural etnográfico - é o caso de reprodução de aldeias indígenas para receber grupos de estudantes. 
A partir da classificação de turismo rural sugerida, acima, claro está, que o turismo rural é praticado no espaço rural, agora, se há ou não participação nas atividades rurais, essa é outra história, portanto, considerando os depoimentos recolhidos e os objetivos deste trabalho, faz-se necessário esclarecer que o enfoque aqui apresentado será sobre o turismo desenvolvido em áreas rurais, abordando a concepção da paisagem individual no espaço rural.

Devido às inúmeras opções de turismo em áreas rurais que a paisagem do cerrado oferece, no próximo capítulo serão apresentadas as características da paisagem no ambiente cerrano.

\section{CAPÍTULO II: CARCTERIZANDO AS PAISAGENS DO CERRADO.}

Neste segundo capítulo, mostrar-se-á a relação entre cerrado e paisagem. A composição do cerrado, sua formação e a importância de sua flora.

Baseado em depoimentos obtidos, em pesquisa de campo, observou-se que os trabalhadores desses empreendimentos, pessoas essas ditas sem muita cultura letrada, voltadas para trabalhos menos valorizados socialmente como no caso dos jardineiros, demonstram um grande conhecimento sobre a fauna e flora da região. Já os outros entrevistados citam a beleza do cerrado no conjunto da paisagem, não demonstrando maior conhecimento ou interesse sobre ele, sabem porém, que, como está na moda preservar, é necessário estar em dia com as palavras do momento. Em relação a isto podemos citar o que diz Gidnami ( s.d, p.14 ) "cada indivíduo possui uma imagem de um lugar, variável conforme seus processos de aprendizagem e seus interesses".

Esses profissionais mais simples demonstram conhecimento obtido na vida, no dia-a-dia em contato com as plantas do cerrado, sendo este utilizado no aproveitamento de algumas folhas e raízes para curar enfermidades, ou na culinária. Um exemplo disto é o pequi que é um fruto muito apreciado na região. Percebeu-se que uma paisagem bastante marcante do cerrado para eles é a imagem de um 
delicioso prato de arroz ou galinha com pequi. Nesse enfoque denota-se claramente a importância do pequi na composição das várias dimensões da paisagem do cerrado. Dimensão esta visual, olfativa ou degustativa. Uma pessoa pode por exemplo recordar-se de uma determinada paisagem forçada pela memória sensorial. Neste caso a paisagem pode ter cheiro, sabor, ouvidos como assinala Pires (2001), referindo-se...

a relação sensorial entre o homem com a paisagem não é somente visual, outras impressões sensoriais repletas de conteúdo espacial e temporal como ruídos, sons, odores e temperaturas estão também presentes na paisagem.

(Pires, 2001, p. 118)

A decisão de fazer o recorte deste trabalho sobre a composição da flora do cerrado, sustenta-se nos fatos dos elementos acima citados serem tão fortes na concepção da paisagem, tanto para mim, quanto para a gente simples deste lugar.

A seguir são apresentadas algumas das espécies típicas que compõem a paisagem do cerrado:

Barbatimão (stryphnodendron adstringens/Leguminosae-Mimosoideae), (Figura 1) encontrado nos ambientes cerrado, campo cerrado e cerradão, sobre solos arenosos e bem drenados. Atinge o porte de 2 a $7 \mathrm{~m}$ de altura.

É uma planta com alto teor de tanino e com propriedades medicinais. O chá da entrecasca é usado para problemas de gastrite, úlceras, afecções hemorrágicas e dores em geral. Também é empregado como cicatrizante. Ao retirar a casca para confecção de remédio, não se deve fazer um anel em todo o tronco, pois o anelamento mata a árvore por falta de circulação da seiva.

Deve-se retirar, apenas, faixas estreitas e alongadas no sentido do comprimento do tronco, facilitando a recuperação da árvore. Esta espécie é protegida por lei, PROIBIDO O CORTE EM ÁREAS URBANAS, tombada no DF como patrimônio Ecológico, pelo Decreto n 14.738/93. 


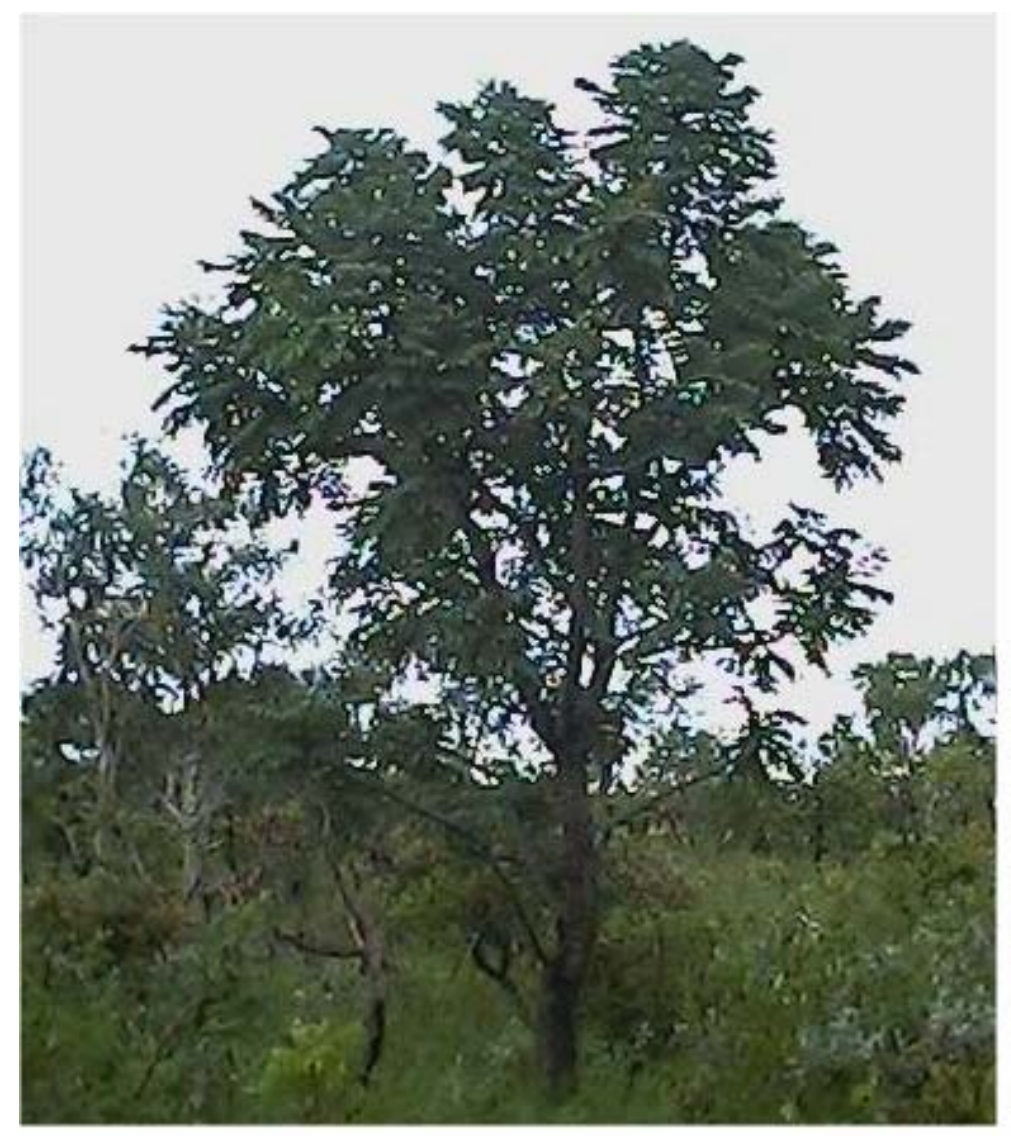

Figura 1. Barbatimão. (Foto: I. V. Pimenta)

A Sucupira-Branca (Pterodon pubescens Benth/Leguminosae-Papilionoideae), (Figura 2), encontra-se nos ambientes cerrado e cerradão, sobre solos bem drenados. Atinge o porte de 5 a $10 \mathrm{~m}$ de altura. É uma árvore que possui grande valor ornamental, por isso é muito utilizada no paisagismo. Suas propriedades medicinais são amplamente conhecidas sendo, inclusive, suas sementes e entrecasca comercializadas em feiras. 


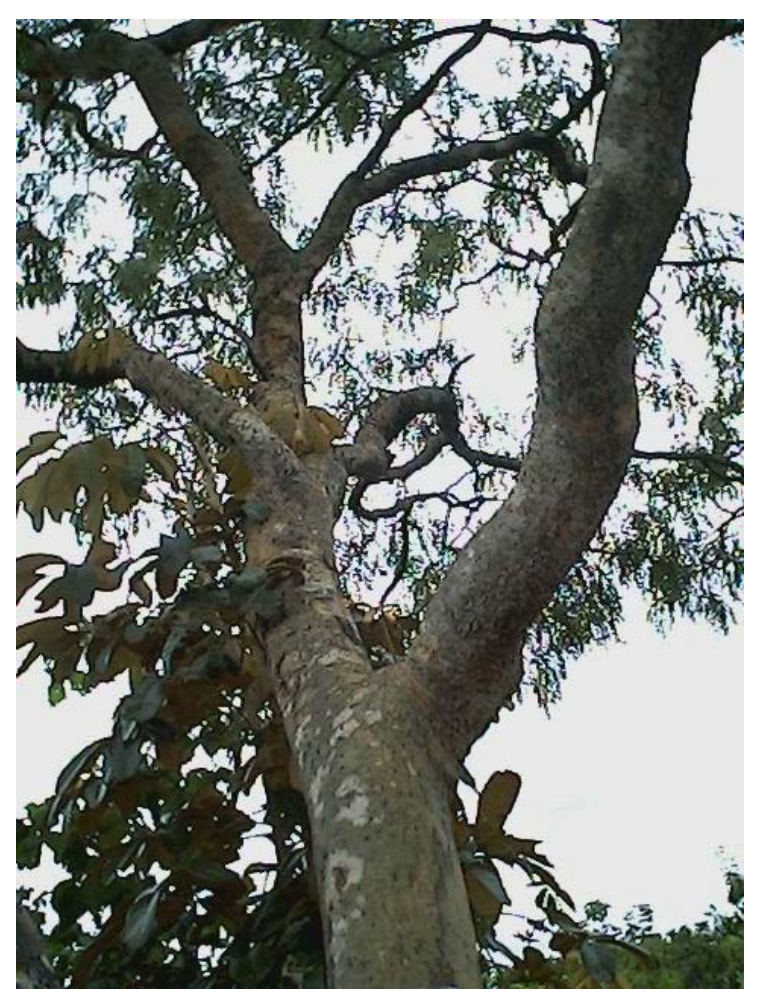

Figura 2. Sucupira Branca. (Foto: I. V. Pimenta)

O fruto oleoso é utilizado no combate às infecções de garganta quando em infusões em água quente. Possui propriedades de fungicida e bactericida. Espécie protegida por lei, PROIBIDO O CORTE EM ÁREAS URBANAS, tombada no DF como Patrimônio ecológico, pelo Decreto n 14.738/93.

\subsection{Alimentos Silvestres}

PEQUI (Caryocar brasiliense camb./caryioceae), (Figura 3) Encontra-se nos ambientes cerrado e cerradão sobre solos bem drenados. Possui porte de 2 a $10 \mathrm{~m}$. Os frutos são globosos, carnudos, com polpa amarelo-alaranjada quando maduro o fruto se abre liberando a semente. O fruto produz um óleo empregado como condimento no preparo de arroz, carnes e na fabricação de sabão caseiro. As sementes também fornecem óleo utilizado na culinária. A polpa é rica em vitaminas A e B1 e possui cheiro e sabor característico sendo muito utilizado regionalmente no 
preparo de licores, e na alimentação, principalmente, cozida com arroz e frango. Abaixo segue uma receita com pequi, representando uma imagem significativa e recorrente na composição da paisagem do cerrado.

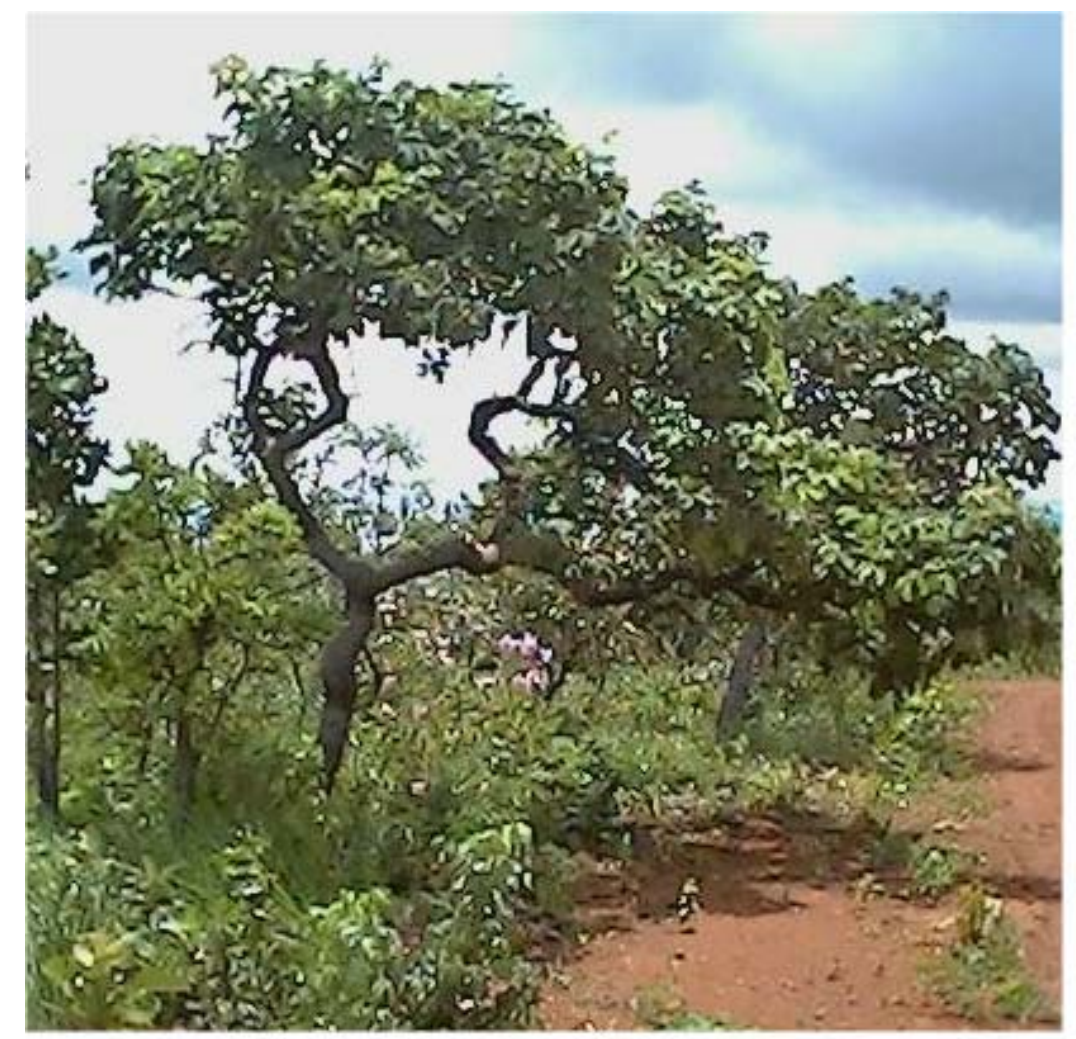

Figura 3. árvore do Pequi. (Foto: I. V. Pimenta)

Receita; arroz e galinha com pequi

Ingredientes

$\checkmark 250 \mathrm{~g}$ de arroz

$\checkmark 4$ a 6 caroços de pequi com polpa

$\checkmark$ cebola, alho, cheiro-verde, sal a gosto

$\checkmark 1$ galinha cortada e temperada

$\checkmark$ outros caroços mais de pequi 
Refogue os caroços de pequi em óleo, sal, cebola e alho, até dourar. A parte, refogue o arroz e acrescente os pequis para que cozinhem juntos. Numa panela de pressão doure os outros pequis, acrescente a galinha e cozinhe. Quando o arroz e a galinha estiverem prontos, junte os dois numa mesma fonte. Salpique cheiro-verde e sirva.

Vale sempre a pena lembrar que o fruto do pequi deve ser roído, apenas, para a retirada da polpa, pois logo abaixo ficam os espinhos.

MANGABA (Hancornia speciosa Gomes/ Apocynaceae) (Figura 4)

Encontra-se no cerrado, sobre solos bem drenados, especialmente em terrenos arenosos. Possui porte de 2 a $7 \mathrm{~m}$. Seus frutos são arredondados ou ovalados, contendo látex em abundãncia quando verdes e, quando maduros, apresentam coloração amarelo-esverdeada com manchas avermelhadas. Perfumados e saborosos. São altamente protéicos e podem ser consumidos ao natural ou em forma de geléias, compotas, sorvetes, licores, sucos e vinagre.

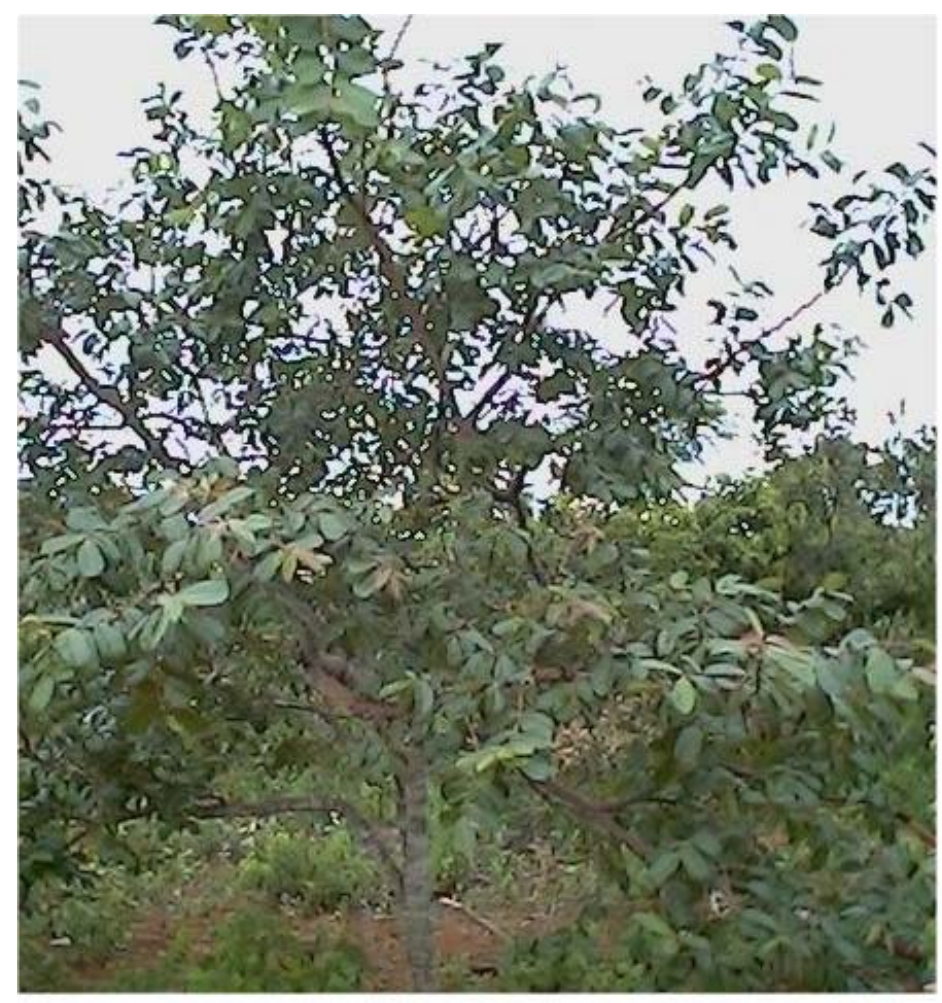

Figura 4. Mangaba. (Foto: I. V. Pimenta) 
JATOBÁ DO CERRADO (Hymenaea stigonocarpa Mart. ex Hayne/LeguminosaeCaesalpinioideae)

Encontra-se nos ambientes cerrado, campo cerrado e cerradão. Possui porte de 6 a $10 \mathrm{~m}$ de altura. Os frutos são vagens lenhosas de cor marrom-avermelhado escuro, com 10 a $15 \mathrm{~cm}$ de comprimento e contendo 3 a 7 sementes por fruto, as sementes são cobertas por uma polpa amarela adocicada, farinácea e de cheiro característico. Essa farinha pode ser consumida ao natural ou utilizada na confecção de bolos, biscoitos, geléias mingau e farofas. O chá da casca é utilizado para problemas renais, infecções intestinais e como cicatrizante. A seiva também é fortificante, muito rica em ferro.

Espécies como o pequi, a cagaita, a mangaba, o buriti são protegidos por lei, e PROIBIDO O CORTE EM ÁREAS URBANAS, tombadas no DF como Patrimônio Ecológico pelo Decreto n 14. 738/93.

O cerrado é uma savana tropical na qual uma vegetação rasteira, formada principalmente, por gramíneas, coexiste com árvores e arbustos esparsos abrangendo cerca de 2 milhões de $\mathrm{Km}^{2}$. A origem da vegetação do cerrado ainda é assunto de discussão, especula-se que a estacionalidade climática, a pobreza nutricional do solo, e a ocorrência de fogo tenham sido os determinantes primários dessa vegetação.

\subsection{Ocupação do Cerrado}

Os primeiros ocupantes do cerrado vieram na "marcha para o oeste" bandeirante em busca de ouro e pedras preciosas no século XVIII. Dois fatores promoveram a expansão agrícola mais recente: a construção da nova capital federal e a adoção de estratégias e políticas de desenvolvimento e investimentos em infraestrutura entre 1968 a 1680. A construção de Brasília e de um sistema rodoviário ligando-a ao núcleo dinâmico do país, permitiram a abertura e ocupação de cerrado, resultando, a partir da década de 70, na expansão da agricultura comercial. Paralela à construção de Brasília, ocorreu, mesmo que de forma desuniforme, uma expansão 
da atividade agropecuária pelo cerrado. Mais significativa têm sido a formação de pastagens e lavouras comerciais, entre as mais relevantes estão as lavouras de soja, milho, arroz, café, feijão e mandioca.

\subsection{Biodiversidade do Cerrado}

Devido a sua vasta extensão territorial, posição geográfica, heterogeneidade vegetal, e por ser cortado pelas três maiores bacias hidrográficas sul-americanas, o cerrado destaca-se por sua biodiversidade.

A flora do cerrado é considerada a mais rica dentre as savanas do Mundo; sua riqueza de 429 espécies de árvores e arbustos é muito superior ao números de espécies das savanas do Suriname e Venezuela. Muitas destas espécies são utilizadas na região para alimentação, medicina, produção de cortiça, fibras, óleos, artesanato e decoração. Mesmo com toda essa Biodiversidade o cerrado não recebeu o status de patrimônio da humanidade concedido a Amazônia, Mata Atlântica, Pantanal e Sistemas Costeiros na Constituição Brasileira.

Os principais obstáculos à conservação da biodiversidade do cerrado podem ser resumidos por: baixo valor atribuído aos seus recursos biológicos; exploração dos recursos visando apenas o lucro, e não o benefício das populações locais; insuficiência de conhecimentos sobre ecossistemas e espécies; os resultados dos poucos estudos científicos realizados não são direcionados na resolução de problemas ambientais; as instituições responsáveis pela proteção da Biodiversidade enfrentam dificuldades organizacionais e financeiras.

A degradação ambiental do cerrado é função do uso que se faz da terra, que depende da tecnologia e investimento aplicados. A intensidade de uso do solo do cerrado não deve ultrapassar sua capacidade de suporte, ou seja, sua capacidade produtiva.

A conservação da biodiversidade do cerrado deve indiscutivelmente aliar-se ao desenvolvimento nacional. No entanto, tal desenvolvimento deve ser baseado na avaliação do potencial dos seus recursos naturais. São prioridades: estabelecer a capacidade de suporte populacional do meio ambiente; manter a integridade dos 
ecossistemas; promover a conservação e utilização sustentável dos recursos biológico; impedir a poluição, minimizando ou cessando a descarga de materiais tóxicos no ar, água e terra; mobilização de segmentos da sociedade, entre os quais, os setores de turismo, agricultura, pesca comercial, saúde pública, industrial, e militar.

Os pesquisadores devem considerar a relevância de seus resultados científicos para o processo de tomada de decisões. São prioridades: buscar informações ecológicas básicas; valorizar economicamente os serviços ecológicos fornecidos pela biodiversidade; determinar as forças que levam à perda da biodiversidade.

\subsection{Caracterização Ecológica do Cerrado}

O cerrado localiza-se predominantemente no Planalto Central do Brasil e constitui-se na segunda maior formação vegetal brasileira, sendo a primeira a Floresta Amazônica. A diversidade de climas, solos e topografia existente nessa extensa região resulta no bioma denominado cerrado - um mosaico de diferentes tipos de vegetação, reflexo de sua heterogeneidade espacial.

A palavra "cerrado" significa "fechado" ou "vegetação densa". Até o final do século passado as formações vegetais do Brasil Central eram conhecidas pelo nome genérico de "tabuleiros". Onde a vegetação rasteira era bem desenvolvida, eram conhecidas por "tabuleiros cerrados". Na segunda metade do século passado, "tabuleiro" passou a ser denominado "campo", e as formações vegetais passaram a ser denominadas "campo limpo", "campo sujo" e "campo cerrado". Mais recentemente, o termo "cerrado" tem sido utilizado para designar a vegetação característica que ocorre na região central do Brasil.

Ao se referir ao cerrado, os ecólogos têm dois conceitos em mente: um fisionômico e outro florístico. Em termos fisionômicos, o cerrado é uma savana tropical, ou seja um bioma no qual árvores e arbustos coexistem com uma vegetação rasteira formada principalmente por gramíneas. As árvores e arbustos distribuem-se 
esparsamente pela vegetação rasteira, e raramente formam uma cobertura arbórea contínua. Em termos florísticos, o cerrado possui uma flora específica que se distingue de outros biomas brasileiros, como a Floresta Amazônica, a Mata Atlântica, ou a Caatinga. Entende-se que o cerrado é constituído por diversos tipos de vegetação savânica que diferem entre si pela abundância relativa de espécies rasteiras e espécies de árvores e arbustos, abrangendo desde formas campestre (campo limpo) até formas florestais (cerradão).

Além dos tipos de vegetação, o cerrado possui grande diversidade de solos e clima. Cinco sub-regiões climáticas são reconhecidas:

$>$ a área norte sob influência Amazônica;

$>$ a área nordeste sob influência da Caatinga;

> a área atlântica sul influência da Mata Atlântica;

$>$ a área continental sul sob influência polar;

$>$ o núcleo central.

\subsection{Tipos de Vegetação}

A vegetação do cerrado, em sua maioria, caracteriza-se por savanas estacionais, com presença de matas de galeria perenes ao longo dos rios. Outros tipos de vegetação ocorrem com menor freqüência, como veredas e campos rupestres.

Há quatro tipos de formas fisionômicas da vegetação savânica: campo limpo, campo sujo, cerrado stricto sensu e cerradão. Elas diferem entre si em relação à composição botânica e à estrutura da vegetação.

A vegetação savânica apresenta também variações em relação à composição botânica. O número de espécies de árvores do cerradão é comparável a algumas florestas tropicais da África. 


\subsection{Hipóteses Sobre a Origem do Cerrado}

Um grupo de cientistas da Universidade de São Paulo descobriu, na década de 40, que havia água disponível nos solos do cerrado abaixo de dois metros de profundidade, mesmo durante a estação seca. Descobriram ainda que as raízes de muitas espécies de árvores do cerrado são profundas, que muitas plantas não apresentam sinais de murcha e que várias espécies de árvores se reproduzem durante a seca. Estas descobertas desbancaram a idéia de que o cerrado seria determinado exclusivamente pela estacionalidade climática.

Além disso, descobriu-se que muitas plantas do cerrado possuem órgãos subterrâneos, os xilopódios, que servem de proteção às plantas contra o fogo. Por causa destas descobertas, concluiu-se que a vegetação do cerrado é condicionada pela ocorrência de fogo.

Surgiu também a idéia de que o cerrado seria determinado pelas condições do solo, ou seja, grande quantidade de alumínio e baixa fertilidade. Uma nova proposta sobre a origem do cerrado foi sugerida no final dos anos 50, é a hipótese do oligotrofismo distrófico, segundo a qual o fato de as árvores não sofrerem restrição de água e haver energia solar abundante na região resultaria que as plantas produziriam por fotossíntese açúcares e gorduras em excesso. Porém, uma vez que os solos são deficientes em minerais, as plantas seriam incapazes de utilizar estes produtos em excesso na elaboração de proteínas, havendo acúmulo de açúcares e gorduras nas folhas. Isso daria às plantas do cerrado um aspecto de plantas de ambiente áridos.

A hipótese mais aceita atualmente considera que a combinação da estacionalidade climática, o baixo nível nutricional dos solos, e a ocorrência de fogo sejam os determinantes primários da vegetação do cerrado. A variação destes fatores no espaço e no tempo seria principal responsável pela diferenciação de tipos de vegetação no cerrado. 


\subsection{Recuperando a Paisagem do Cerrado}

Certamente a devastação da mata do cerrado nesta regiâo ainda é um problema sério e grave, embora muitas leis de preservação estejam em vigor, pois o cerrado perde espaço para áreas de loteamento, áreas agrícolas e pastoris, entretanto é possível encontrar iniciativas que tentam contribuir com a recuperação e repopulação de espécies tanto arvóreas, como animais, em áreas desmatadas. Neste sentido podemos mencionar a visita de campo feita ao Laboratório FLORATIVA, localizado no Núcleo Rural Saia Velha onde trabalham com clonagem de espécies nativas principalmente do cerrado, com a finalidade de reintroduzir estas espécies na paisagem natural do cerrado.

Em entrevista concedida para esta monografia, o técnico do Laboratório FLORATIVA, Senhor Elias, nos apresentou todo processo de clonagem, de uma das espécies nativas mais valorizadas do cerrado, a Canela-de-ema (Vellozia squamata), constatando os seus diferentes estágios de evolução. (Figura 5)

São ações como estas e outras como a formação das Áreas de Proteção Ambiental - APA's e Ongs que trabalham em prol da preservação do meio ambiente e que produzam ações relevantes no tocante à recuperação da mata do cerrado, que farão com que as pessoas se concientizem cada vez mais que fazemos parte meio.

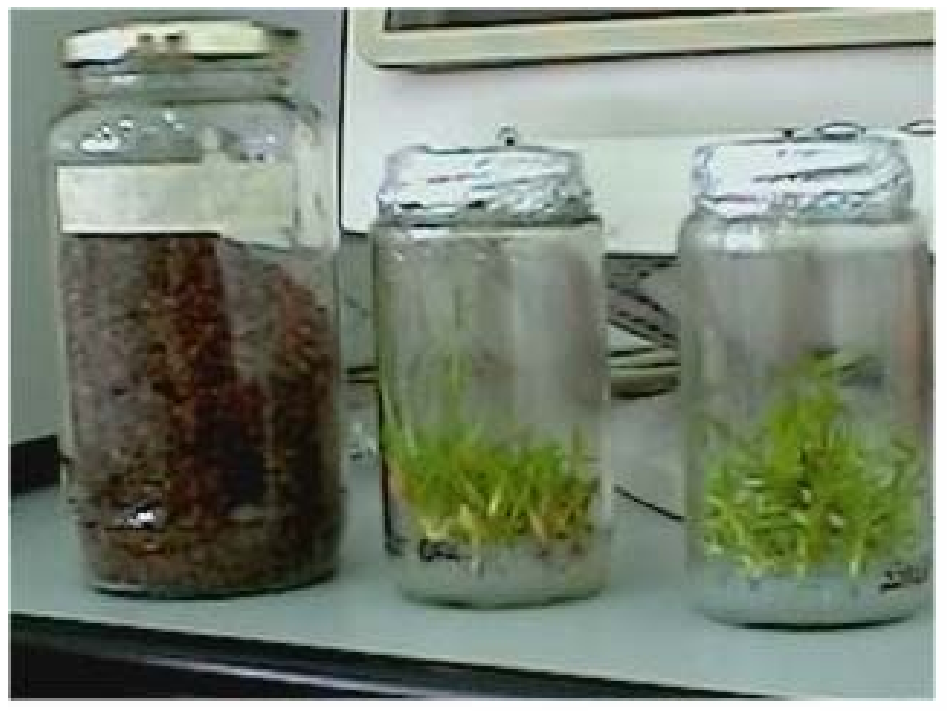

Figura 5. Canela-de-ema. (Foto: I. V. Pimenta) 


\section{CAPÍTULO III: IMAGINÁRIO E PAISAGEM TURÍSTICA.}

\subsection{Comentários Sobre o Imaginário}

O imaginário existe ou é pura imaginação? A palavra imaginário por si só representa algo que não existe, que não é concreto, porém "existe" no campo do inconsciente, da representação.

Do ponto de vista da psicologia, sem memória ou conhecimento não poderia haver imaginação.

A memória social faz parte da representação do mito da identidade nacional. Somos aquilo que todos são. Queremos aquilo que todos desejam. Assim age a mídia criando estereótipos que nos representam como um todo. Como se todos fossem um. Há porém a individualidade. A memória individual que temos e que nos remete ao interior de nós mesmos. Estamos sempre buscando elementos com os quais nos identificamos. Claro que todos buscamos e temos uma imagem de paraíso, porém esse paraíso ao ser materializado na construção de um empreendimento turístico, tenta ser uma representação coletiva. É preciso criar o sentimento de pertencimento, afinal piscina, água, cachoeira, muito verde, muita mata, belezas naturais fazem parte do imaginário de qualquer indivíduo, é um ideal coletivo, são ícones que herdamos coletivamente a partir de normas de comportamentos repetidos e condicionados através da escola, da família da televisão, da propaganda. Bittencourt (1986), assim conceitua imaginário: "O imaginário pode ser definido como um conjunto de imagens que procedem a inserção do indivíduo na cultura, ou seja, no registro simbólico” (Bittencourt ,1986, p. $60)$.

Quando as imagens que povoam o imaginário coletivo são representadas num espaço turístico elas tornam-se espelhos porque muitos se vêm refletidos nelas, e disso depende o sucesso ou fracasso da massificação de uma imagem turística, afinal apesar da tentativa de unificação dessa imagem desejada somos donos, cada um, de seu próprio imaginário. Por isso, essa imagem deve ser flexível, admitindo 
ajustes quando necessário, como podemos perceber nesta passagem, de Bittencourt (1986), "a sociedade toda vive em cada um de seus membros"

\subsection{Conceituação de Paisagem}

Em primeiro lugar veremos o diz o dicionário sobre paisagem.

Paisagem. f. 1. Espaço territorrial que se abrange num lance de vista. 2. Panorama. 3. Desenho ou quadro representando uma cena campestre.

Dicionário Essencial da Língua Portuguesa - Volnyr Santos

$\mathrm{Na}$ maioria das vezes confundimos paisagem com panorama, tendo em vista que é um termo usado como sinônimo até mesmo na definição do dicionário, a paisagem pode ser vista como uma construção psicológica, depende da posição e da memória afetiva do observador, uma mesma paisagem pode representar tudo para uma pessoa e nada para a outra. Já "panorama" reúne todo o espaço físico que compreende o campo de visão, a totalidade do olhar. Paisagem e panorama são como dualidades como olhar e ver, som e ruido, sabor e paladar são fatores que dependem de aspectos afetivos, psicológicos, culturais e também do momento, do lugar e do porquê. Para Collot (1990, p.23) "é preciso não confundir paisagem e panorama: o panorama tende a reunir o espaço do mapa e sua visão declivosa."

O turismo enquanto atividade turística descreve panoramas principalmente através da propaganda, no intuito de vender imagens que se aproximem do paraíso, é o desejo de encontrar "a paisagem" neste panorama que leva o turista a se deslocar promovendo assim a atividade turística.

Por isso paisagem e turismo são duas realidades intimamente relacionadas. A paisagem é um elemento substancial do fenômeno turístico e, portanto, um recurso de grande valor no desenvolvimento e na consolidação da oferta turística. 
Podemos redescobrir uma mesma paisagem num mesmo panorama várias vezes no dia pois ela, a paisagem, depende da luminosidade, do horário, da distância, do nosso estado de espírito, dos vários deslocamentos que fazemos nesse panorama redescobrindo novos ângulos de uma mesma imagem, isto é, do ponto de vista da observação.

Assim como paisagem remete a panorama, também, paisagem se confunde com natureza. A natureza existe em si e a paisagem vai compondo quadros e emoldurando-os de acordo com a percepção individual que se tem dela. O turismo enquanto fenômeno usa e abusa da paisagem que sofre com os processos constantes de transformação da natureza. A paisagem sofre alteração por processos naturais decorrentes no desgaste natural das plantas, da migração da fauna, da poluição ambiental, de acordo com o tempo, necessidade e evolução da sociedade. Como conclui o trecho abaixo:

A qualidade visual de um lugar ou paisagem pode se alterar com o tempo e a sociedade poderá valorizá-los diferentemente. Esta qualidade pode ter um alto valor em determinado período e, em decorrência de alguma alteraçãoe/ou no tipo de uso, poderá em outro período/momento apresentar a qualidade reduzida.

(Neves, 1992, p. 109)

A frequência da observação também é um fator importante na composição da paisagem. É diferente olhar uma imagem uma vez e vê-la cotidianamente. Imagine por exemplo a chuva que cai devagarinho, fina sobre um campo verde, se essa imagem é vista constantemente não damos a ela o valor merecido ou o por-do-sol no Distrito Federal que é um dos mais belos do Brasil, quantas pessoas na rudeza da vida urbana preocupam-se com essa imagem?

Para ratificar tal afirmação veja o que diz Meining (1978):

As paisagens se mostram diferentes em função de quem as observa, dada a carga cultural, maneira e frequência da observação. Qualquer paisagem é composta não apenas pelo que estende defronte dos 
olhos, mas pelo que se encontra dentro das mentes, ou seja, somos capazes de ver aquilo que conseguimos interpretar.

(Meining (1978, p.23)

Assim, segundo Collot (1990) devemos observar três aspectos na definição de paisagem:

a) $\quad$ O ponto de vista que se refere ao ponto de observação da paisagem;

b) A parte que se refere a área observada;

c) O conjunto que se refere ao todo harmônico responsável pela beleza ou feiura da paisagem e é o que dá significado, é o que dá sentido a quem olha.

Um fato importante a se observar é que a imagem, por mais metafórica que seja, deve ter um pé na realidade, para que não cause frustração em quem a busca. Como podemos constatar neste trecho de Gidnami (s. d):

A imagem se distancia muito da realidade e gera insatifação no cliente, fazendo com que ele avalie o produto comprado como sendo um produto sem qualidade. Por isso, que por se tratar de uma representação, a imagem busca ser esclarecedora e deve tentar refletir a realidade da melhor maneira possível, a fim de evitar frustrações no consumidor.

(Gidnami, s.d, p. 14)

Como exemplo, podemos citar o caso relatado pelo chefe de recepção Juliano, do Hotel Fazenda Retiro das Pedras, um dos empreendimentos visitados em pesquisa de campo, que diante das imagens dos folders ou ainda as veiculadas na internet os clientes ligam com a intenção de saber se o Retiro "é isso tudo mesmo". O chefe de recepção Juliano disse saber o quanto é importante corresponder às expectativas dos clientes. Por isso, ciente de que a imagem do Retiro está associada à imagem de paraíso, procura brindar os clientes com um excelente tratamento a fim de que se sintam satisfeitos e encantados. 
O encantamento faz parte da estratégia publicitária que se utiliza do poder de convencimento de uma bela imagem, que satisfaça o imaginário do turista para conduzi-lo a utilização do serviço oferecido, para que este passe do estágio orgânico da imagem, chamada inicial à imagem induzida, esta que se utiliza a propaganda.

Buscamos na paisagem o equílíbrio e o equilíbrio se traduz numa imagem que satisfaça as nossas aspirações, nossos desejos. Essa imagem reflete esteticamente a idéia do belo, do maravilhoso, do divino e aí contruímos a imagem de paraíso. Qual é o seu paraíso?

\section{CAPÍTULO IV: A CONSTRUÇÃO DE PARAÍSO}

\subsection{Conceituação Etimológica e Histórica de Paraíso.}

Como diz Aoun (2001) a palavra paraíso têm sido utilizada pela indústra da propaganda turistíca com relação ao universo do sagrado. A palavra paraíso devido à dimensão semântica estimula o imaginário, sendo assim, objeto especulação na propaganda turístaica. Vejamos, a partir da linguagem referencial, o que vem a ser um paraíso.

Paraíso. m. 1. Lugar onde, segundo o velho Testamento, Deus colocou Adão e Eva logo depois de criados. 2. Lugar delicioso.

Dicionário Essencial da Língua Portuguesa - Volnyr Santos

Como constata Aoun (2001) paraíso nos remete a santuário, templo, Éden, natureza, desejo, cobiça e, porque não, amor, sexo, paz, boa comida. Poderíamos escrever um universo de palavras e expressões relacionadas à paraíso, pois todas nos recordam coisas boas e prazerosas, talvez, por isso, seja tão utilizada pela mídia na indústria turística, principalmente sendo esse produto "imaterial e intangível" (Rushmann 1991, p. 30) e "todo consumidor espera obter do produto escolhido o que esse the prometera " (Gidnami, s.d p.13). 
Podemos apreciar, pela forma ampla como se define este conceito, que há um aspecto físico (lugar) e outro imáginário, que aponta para um estado de espírito, o produto turístico é apresentado com fotos sugestivas e acompanhadas de palavras que parecem escolhidas cuidadosamente sugerindo promessa de satisfação.

Nas referências bibliográficas, é possivel encontrar este conceito relacionado a diversos aspectos da cultura universal, desde relatos bíblicos, passando pelas diferentes civilizações ao longo do tempo, até chegar aos nossos dias, com uma concepção relacionada a propaganda turística, onde paraísos são vendidos.

Assim, percebe-se que esta palavra, possui uma conotação simbólica extremamente expressiva, que tem relação com a origem do homem. Paraíso, conduz o indivíduo ao mundo dos sonhos e felicidade, despertando desejos íntimos da alma, em busca do mundo perfeito (Aoun, 2001). Por isto, quando um lugar é denominado paraíso é porque possui um conjunto de qualidades atraentes que podem conduzir o indivíduo a um estado de sonho e realização.

Deve-se lembrar que não é qualquer lugar que pode ser denominado paraíso, depende de inúmeros fatores, desde aspectos sociais até políticos e de conservação. Esta reflexão é válida também para o estado de espírito, do indivíduo que se sente no paraíso.

Do ponto de vista da propaganda, percebemos, claramente, a exploração consciente da palavra paraíso, é importante citar o trabalho de Aoun, (2001), no qual se faz uma análise da utilização da palavra paraíso em algumas revistas de circulação nacional. Nesse enfoque devemos destacar que há lugares que são denominados paradisíacos pelo fato de encontrarem-se distantes e isolados, ou po que fazem um chamado à preservação do ecosistema e a cultura. Porém, há ainda paraíso que é de propriedade privada, possuindo "dono e polícia".

Aoun (2001) mostra, também, em outra passagem da referência, o aspecto de exclusividade do lugar. Para isto o visitante deve ter atitudes respeituosas perante a natureza e uma identidade com os valores conservacionistas. Contudo, no mundo da propaganda, que pode-se dizer ideológico, a natureza intacta em contraste 
com a ideologia ambiental, faz do paraíso uma mercadoria, posta a venda para o turismo, com um significado meramente simbólico.

Enfim, podemos afirmar que paraíso é uma conjunção equilibrada e harmoniosa entre o aspecto do lugar e o estado da mente do ser humano. Sem essa combinação faz-se impossível vivenciar o paraíso. Vale ressaltar que o grande desafio do século XXI será não mais conscientizarmos as pessoas sobre o valor de preservação dos paraísos naturais, porém, por em prática, ações que preservem esses paraísos para que as gerações futuras tenham direito a desfrutar do sonho tanto quanto nós tivemos.

\subsection{O Mito Brasileiro de Paraíso}

Repetidamente, ao longo dos anos, a terra brasileira é comparada por muitos autores ao Paraíso Terrestre, característica essa que permite afirmar ser esse um mito fundador da nossa nacionalidade. O nos leva a crer que assimilamos e perpetuamos o olhar do colonizador sobre nós mesmos. O mito ou discurso fundador o qual nos passa os europeus, é o de que a nossa terra é a materialização do paraíso, mito, este, que embora reconhecido pelo povo, gera entre nós mesmos piadas/críticas como a relacionada abaixo:

Quando Deus criou o Brasil, ouviu uma série de reclamações. Habitantes de outros países achavam injusto que ele tivesse criado uma terra tão linda, sempre banhada de sol, sem terremotos, maremotos, furacões, desertos e tempestades de neve. "Assim não dá", disseram em coro para Deus, que logo calou as reclamações, dizendo: "Esperem pra ver o povinho que vou colocar lá.

(Sousa.2002. p.35)

Discurso fundador, explica Marilena Chauí, é aquele que não cessa de encontrar novos meios para exprimir-se, novas linguagens, novos valores e idéias, de tal modo que, quanto mais parece ser outra coisa, tanto mais é repetição de si mesmo. (CHAUí, 2000. p.10) 
E ainda para Eni Orlandi (1993), é próprio do discurso fundador funcionar como referência básica no imaginário de um país, possibilitando a formação de outros discursos, como os relacinados abaixo.

Todo Brasil é um jardim em frescura e bosques, e não vê em todo o ano árvore nem erva seca. Os arvoredos se vão às nuvens de admirável altura e grossura e variedade de especies. Muitos dão bons frutos, e o que Ihes dá graça é que há neles muitos passarinhos de grande formosura e variedade e em seu canto não dão vantagem aos rouxinóis, pintassilgos, colorinos e canários de Portugal...

(Pe. José de Anchieta. Cartas.In: Sousa.2002.p. 4)

O que há de extraordinário é que as árvores nunca perdem as folhas como as nossas no inverno; em qualquer época têm elas folhas, flores e frutos; pode-se dizer, de certo modo, ser esta terra _ Plantatio dexterae exelsi _ uma planta da direita, isto é, da providência de Deus; pois nada aí cresce que não seja em virtude de sua graça exclusivamente.

(Claude d'Abbeville. História da missão dos padres capuchinos na Ilha do Maranhão e terras circunvizinhas. In: Sousa.2002.p. 4)

Do que a terra mais garrida

Teus risonhos lindos campos têm mais flores.

Nossos bosques têm mais vida

(Osório Duque Estrada. Hino Nacional Brasileiro. In: Sousa.2002.p 4)

Brasil, estas nossas verdes matas

Cachoeiras e cascatas de colorido sutil

E este lindo céu azul anil

Emolduram aquarela o meu Brasil

La la la laiá

La la la laiá

(Silas de Oliveira. Aquarela Brasileira. In: Sousa.2002.p 4)

Falemos francamente. Está atrás do Paraíso Terreal. Acredita na realidade física do éden.

- É.

_ E espera encontrá-lo em alguma parte do globo. 
Sim.

_ Pois não está sozinho nisso. Muitos homens pensam como você. Uns procuram uma ilha, outros as sete cidades, ou o eldorado. Há povos que até puseram o Paraíso nos mapas... nos antigos pergaminhos a e na literatura céltica você encontra a ilha O'Brazil, que na língua arcaica da Irlanda significa "ilha afortunada".

_ O Paraíso ... chamado Brasil? _ gaguejou Diogo.

JAF, Ivan. Atrás do paraíso. In: Sousa.2002.p 4)

\subsection{O Paraíso Relacionado com as Imagens do Cerrado}

Ao percorrermos alguns lugares que fazem parte do cerrado nesta região, podemos visualizar claramente os diversos aspectos da significação do paraíso e a relação que este tem com a paisagem do cerrado. Muitas vezes observam-se grandes áreas absolutamente devastadas, ora por máquinas, ora pela crueldade do fogo e a impressão intuitiva que vem à cabeça de algum observador, é de destruição e o "antiparaíso". Porém para outros, nesses lugares, podem perfeitamente ser reconstruídas imagens que venham a compor um paraíso, que estará constituído como uma espécie de oásis no meio da mata do cerrado.

Por outro lado, é possível achar lugares onde se misturam a mata do cerrado com a paisagem construída convivendo em perfeita concordância e equlíbrio permitindo aos visitantes encontrarem o lugar perfeito para se sentir no seu paraíso.

Porém também, há aqueles espaços, onde pode-se encontrar somente mata do cerrado, nos quais espécies nativas de plantas e animais usufruem do que mais belo a natureza oferece, claro, às vezes, estes espaços são descobertos pelos visitantes permitindo que eles se fartem de beleza e vivenciem estes paraísos naturais. Geralmente estas regiões são áreas públicas preservadas ou territórios particulares de conservação.

Mas, como o paraíso não apenas é encontrado no aspecto físico e visual, há outras imagens que constituem o paraíso do cerrado. Usufruir dos frutos produzidos pelas árvores do cerrado é uma leitura altamente interessante e que merece especial atenção, devido fundamentalmente ao fato que muitas vezes quem constrói este 
paraíso é um indivíduo simples, de pouca formação erudita, mas com um legado cultural do cerrado extremamente amplo, podendo transformar, o que para alguns é um objeto ornamental, em deliciosos e exuberantes pratos, ou simplesmente uma folha singela num poderoso remédio.

Percebemos que na construção do paraíso no cerrado as possibilidades são vastas, dependendo do ser humano o tempo e lugar que o encontrará, sendo para isto necessário que exista o interesse e oportunidade da descoberta das imagens apropriadas para a constituição do conjunto equilibrado denominado paraíso.

No próximo capítulo mostram-se alguns lugares e pessoas que apresentam alternativas no sentido de buscar, nas diferentes imagens do cerrado, o seu paraíso.

\section{CAPÍTULO V: REDESCOBRINDO PAISAGENS}

\subsection{Paraíso Natural versus Paraíso Construído}

Quem não busca eternizar através da fotografia, as imagens de uma viagem de férias numa praia linda ou numa bela fazenda. O album de fotografias fala por si só, é um livro em que se pode saber o estado de espírito de uma pessoa, apenas pelas imagens registradas. A partir da fotografia expomos muito mais do que estamos dispostos a dizer. Aprendemos a reconhecer o outro somente por imagens mas, também, nos denunciamos através dela, porque é como "transformar o próprio vivido numa maneira de ver" ( Susan Sontag.in: Maresca, 1998. p. 143)

A fotografia como sinônimo de imagem favorece a aproximação com o outro e consigo mesmo, é como chegar em um bar e pedir uma garrafa de cerveja, é um convite a conversa, é um prazer pois revive-se os momentos supostamente agradáveis, retorna-se a lugares esquecidos. "Enquanto substituto visual dos objetos e seres, a fotografia pode reativar esta mesma ligação intrínsica das palavras ao visível" (Maresca,1998, p. 145) A fotografia funciona como uma tentativa de retratar visualmente o imaginário, é como se imaginário fosse materalizado. 
A fotografia é uma imagem muda que vai além da linguagem. Quem trabalha numa empresa turística, trabalha na visão do outro, apropriando-se de imagens alheias. Disso vive, depende e resulta em sucesso ou fracasso do fenõmeno turismo.

Neste capítulo fara-se-á a análise dos materiais coletados por meio de entrevistas, depoimentos e imagens realizadas junto aos profissionais que trabalham nos estabelecimentos que exploram o turismo em espaços rurais. A idéia é trabalhar o conceito de paraíso e paraíso pessoal junto a profissionais desses estabelecimentos turistas. A partir dos depoimentos percebemos que para que se tenha o privilégio de ser chamado de paraíso, é necessário ter equipamentos naturais mínimos para isso. As duas propriedades escolhidas para esse trabalho foram o Hotel Fazenda Retiro das Pedras por chamar a atenção pela beleza e qualidade das imagens veiculadas em seu folder e o Clube Águas Correntes Saia Velha por explorar junto as belas imagens do fôlder a seguinte inscrição "Venha conhecer o paraíso das águas", despertando a atenção, a curiosidade e a imaginação de quem o lê.

\subsection{Retiro das Pedras}

Vamos conhecer um pouco do Hotel-fazenda Retiro das Pedras, localizado na DF 495, km 08, Brasília - DF.

Este é um estabelecimento que possui uma excelente infra-estrutura, o Retiro oferece chalés com TV, ar condicionado, frigobar e telefone; Restaurante; bar; cafeteria e sorveteria; biblioteca e loja de conveniência; quadra de tênis; spa; trilhas ecológicas; Cavalos; piscina aquecida e coberta; piscina de 70 m; sauna; centro de convenções; sala de jogos; capela.

Os chalés têm capacidade para até cinco pessoas, todo o Retiro das Pedras está envolto numa atmosfera aconchegante e uma exuberante vegetação, onde se misturam o cerrado e belos jardins construídos pelo homem convivendo em perfeita harmonia. 
O folder do Retiro (ver Anexo I) é ricamente ilustrado e traz e seguinte legenda na capa "Retiro das Pedras - Um brinde a natureza", sobre uma belíssima composição de imagens, no qual o destaque é uma ponte sobre a piscina de $70 \mathrm{~m}$, o folder traz ainda pessoas bonitas e felizes fazendo um brinde sobre uma bela mesa muito bem servida e no fundo da imagem a copa de uma árvore. Essas imagens mostram como o paraíso é maravilhoso, onde se é feliz (obrigatoriamente feliz) e bebe-se e come-se muito bem. É um paraíso classe A, para pessoas privilegiadas, embora o chefe de recepção, Juliano ressalta, na entrevista, que o lugar recebe turistas de todas as classes.

Abrindo o folder encontramos outras fotos em que se retoma e reforça a idéia de natureza exuberante, através das fotos de uma coruja, de uma flor e de uma bela paisagem; além de reforçar as imagens com a palavra "natural" que nos remete ao politicamente correto, essa idéia de preservação ambiental é reforçada com a seguinte passagem:

Localizado a apenas $30 \mathrm{~km}$ do aeroporto de Brasília, o Hotel-fazenda Retiro das Pedras situa-se em uma região rica em vegetação cerrana e matas ciliares. Integrou-se à natureza com beleza e harmonia, respeitando nosso ecossistema e preocupando-se toda a fauna que contribui para o grande sucesso das trilhas ecológicas.

Cavalos, macacos, pássaros raros fazem do Retiro das Pedras um passeio indispensável para o conhecimento de animais muitas vezes esquecidos pelas crianças, resgatando o contato com o campo e com a nossa biodiversidade.

(Informação do folder do Retiro da Pedras).

Nesse enfoque, destacaremos a observação feita pelo chefe da recepção Juliano: "o proprietário não permite que os animais silvestres como cobras, sapos, sejam mortos, eles devem ser devolvidos à natureza, pois somos nós que estamos invadindo seu espaço". Percebemos que além das imagens e textos do folder, os funcionários do estabelecimento são coerentes com a proposta dos seus serviços apresentadas nas imagens da publicidade do folheto. 
Ainda no folder, nos chama a atenção o contrate de cores das imagens, principalmente das tomadas aéreas da piscina: essa imagem é tão bonita que questionados alguns funcionários, sobre sua imagem favorita, destacaram exatamente esta, pelo contraste dos tons azul da piscina com o verde do entorno. Não é de se admirar que os clientes liguem para saber se realmente essa imagem do folder corresponda à realidade.

O Hotel Fazenda Retiro das Pedras, é um empreendimento rural que pode ser classificado de hotel-fazenda pois possui uma infra-estrutura, que sofreu reformas em 2002, para atender os hóspedes que procuram tranquilidade, sofisticação associada às belas paisagens naturais e artificiais. Aqui, o hóspede pode participar de atividades ligadas ao meio rural como trilhas, passeios a cavalo, sem envolver-se num clima de fazenda e com o conforto dos bons hotéis.

O Retiro se apresenta como um local onde se pode participar de convenções de uma maneira agradável, desfrutando de um lugar confortável e charmoso. O lugar parece pensado para tirar às preocupações das pessoas em relação ao trabalho rotineiro, ao estresse dos escritórios, ao engarrafamento do trânsito, visto que em seu folheto dão ênfase ao Spa para que as pessoas possam fugir do estresse do diaa-dia.

Para analisar a forma como é vista a paisagem das pessoas que trabalham e frequentam o retiro, descreve-se a seguir alguns relatos obtidos:

A primeira pessoa entrevistada é o chefe da recepção, Juliano, que demonstra desenvoltura para lidar com o atendimento ao público e um excelente domínio das tarefas recomendadas, embora não seja um profissional especialista na área de turismo, a prática e o dia-a-dia, tem-Ihe permitido adquirir competência suficiente para desempenhar a sua função. Na longa conversa estabelecida, ao ser consultado em relação à imagem de que mais gosta ou que remete ao ideal de paraíso pode-se destacar a imagem tomada aérea da piscina, pelo contraste do azul e o verde (Figura 6), assim como a entrada do restaurante, (Figura 7) que segundo ele, representa a organização e bom gosto do lugar. 
E o lugar tenta, em todos os sentidos, aproximar-se da visão de paraíso que fazemos em nosso inconsciente.

O recepcionista Junior indica como imagem de paraíso a mata do cerrado, e disse ter um vasto conhecimento do cerrado, aliás, ele faz referência a vários frutos da flora e cita que seus pais utilizam várias espécies no tratamento de doenças, vemos que estas imagens possuem a influência das vivenças familiares. Porém. ele remete-se a outra imagem marcante, do ponto de vista da profissão, como é o caso da ponte sobre a piscina.

Percebe-se que este funcionário, coloca entre suas paisagens preferidas as imagens do cerrado, fato este, que pode estar associado ao pouco tempo de convívio como funcionário do estabelecimento ( três meses). Ao meu ver, neste caso, ele possui ainda um olhar desautomatizado sobre a paisagem.

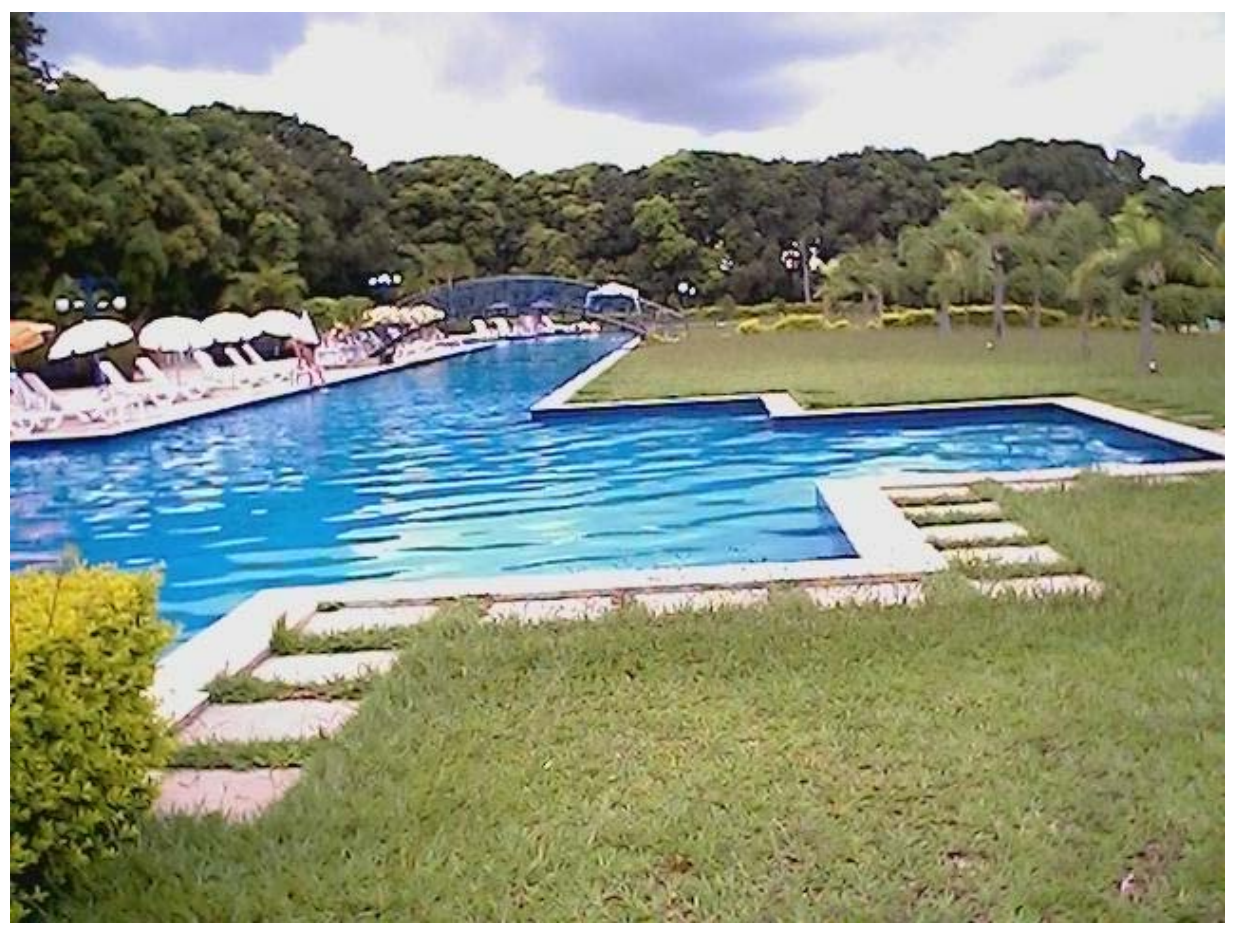

Figura 6. Foto da Piscina do Retiro das Pedras. (Foto: I. V. Pimenta) 


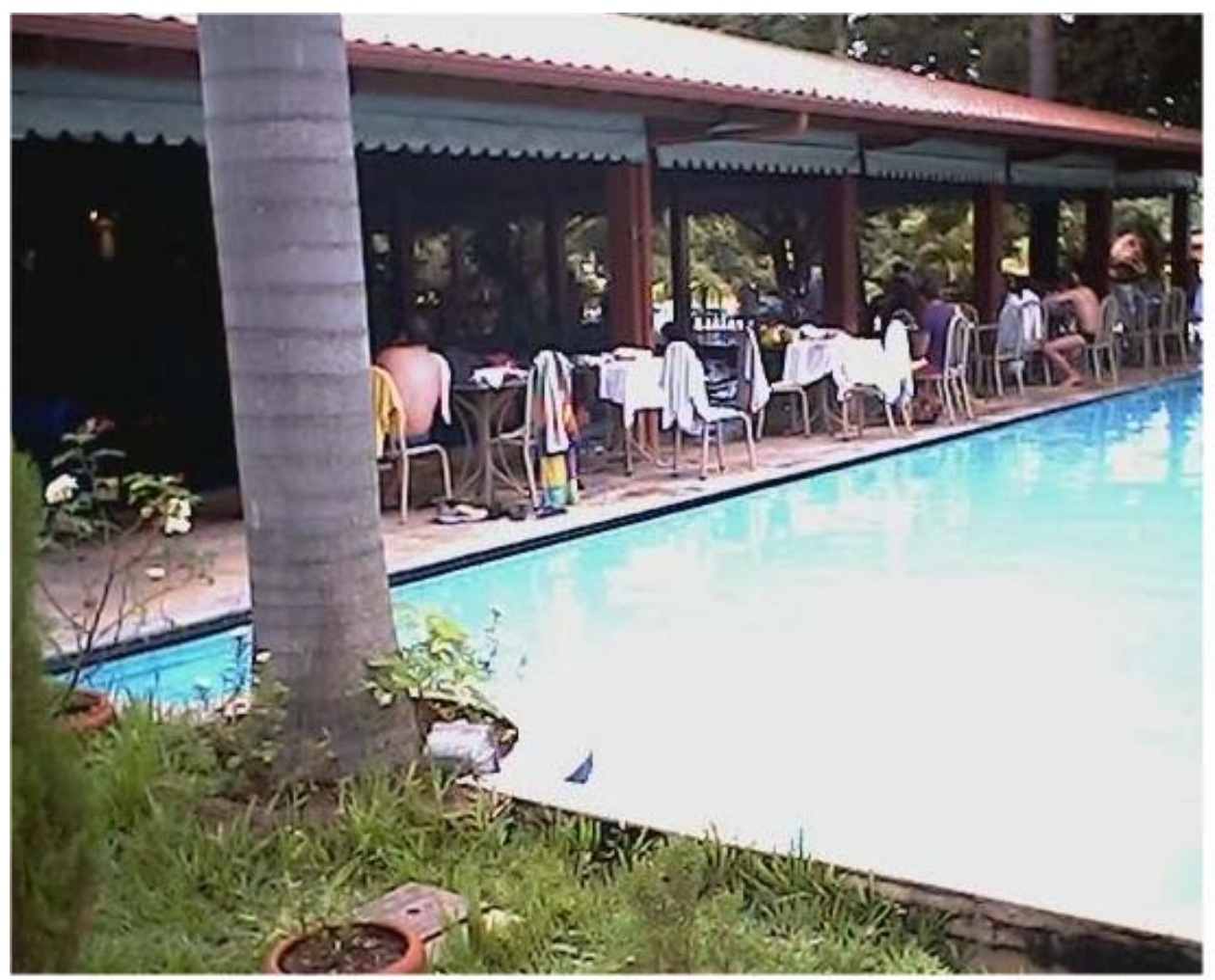

(Foto: I. V. Pimenta)

Figura 7. Imagem do restaurante.

Um outro funcionário que trabalha em serviços gerais, o senhor Luiz, um cidadão simples, que por sinal é um dos trabalhadores mais antigos da casa, surpreende citando as características culinárias e medicinais de diversas espécies que são encontradas na região cerrana. Ao ser questionado sobre uma paisagem do cerrado que Ihe é familiar, imediatamente, a imagem anterior é resgatada e ele logo comenta sobre o prato de galinha com pequi (Figura 8), inclusive relatando que, o outro dia foi recolher pequis na mata para preparar este prato para os hóspedes. Ele também destaca a paisagem da piscina e do entorno, aqui mais uma vez, nota-se uma imagem, que ao contrário da citada anteriormente, vem fortemente carregada pela influência do ambiente profissional. 


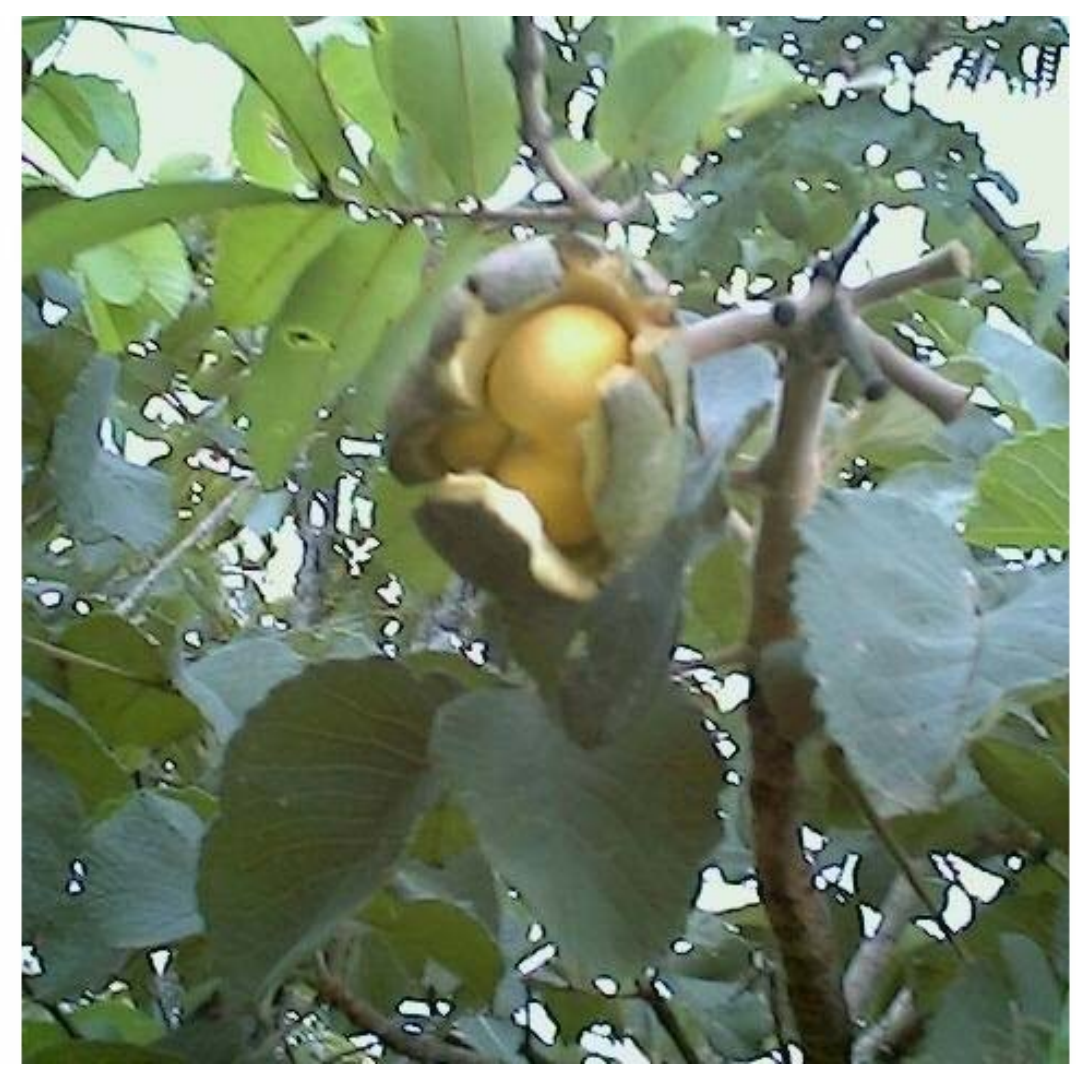

(Foto: I. V. Pimenta)

Figura 8. Fruto do pequi.

Continuando com as indagações encontramos uma hóspede, Carmem Bittencourt, funcionária pública, moradora de Brasília e hóspede assídua do Retiro, que demonstra fascínio pelo lugar devido à exubertante beleza de contrastes, atendimento, ambientação, comida e proximidade da Capital Federal. Ao ser consultada em relação a uma paisagem marcante, ela pensa um momento e decide pelas verdes e frondosas colinas (Figura 9) que se apresentam logo à frente do Retiro. 


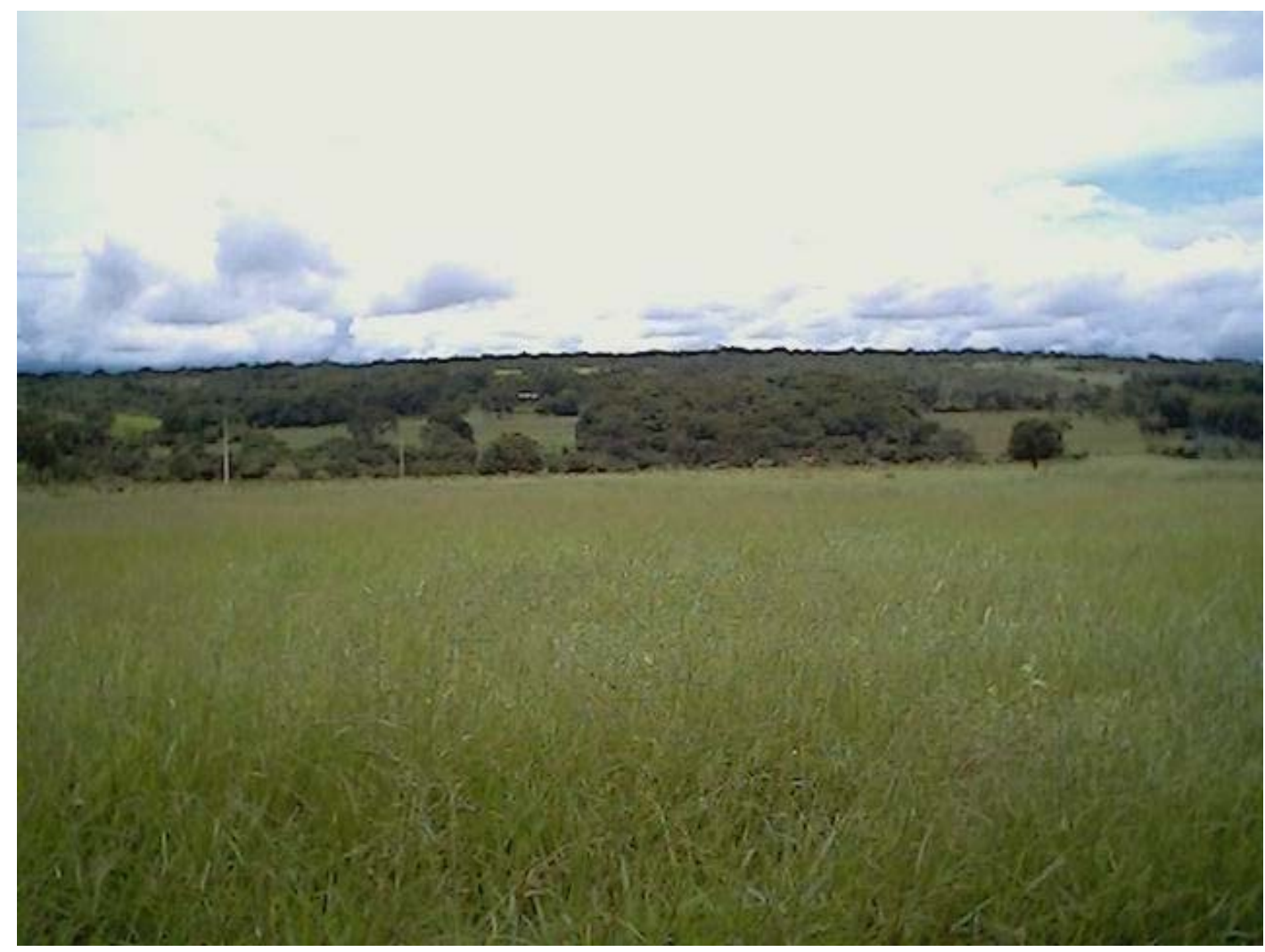

Figura 9. Imagem mencionada pela turista Carmen. (Foto: I. V. Pimenta)

\section{3 Águas Correntes Saia Velha}

Localizado à $26 \mathrm{~km}$ do balão do aeroporto de Brasília, sentido Valparaízo km 05. O empreendimento Águas Correntes Saia Velha é um clube de entretenimento, lá o turista pode passar o dia desfrutando de belíssimas piscinas naturais de águas correntes, cachoeiras lindissimas e quedas d’águas. Possui, ainda, restaurante, playground, churrasqueiras individuais, passeios a cavalo, campos de futebol, sinuca, área para banhos de sol e pesque-pague.

Embora seja um empreendimento turístico pensado para funcionar em uma fazenda, não pode ser classificado como fazenda-hotel pois não oferece aos turistas, que ali buscam lazer, a convivência com as rotinas que normalmente se desenvolvem em uma fazenda. Aqui o recurso natural mais explorado é a água, toda 
a infra-estrutura foi pensada em função dela, toboágua, rampa, piscinas de águas correntes.

Segundo o diretor administrativo Sr.Gilberto Lopes, o clube existe desde 1997. Inicialmente era uma fazenda e com o intuito de aumentar a receita, os proprietários resolveram explorar o turismo, já que a fazenda dispunha de uma belíssima cachoeira. Toda infra-estrutura foi desenvolvida com recursos próprios.

Questionados sobre a paisagem que gostaria de retratar, o senhor Gilberto selecionou duas. Numa primeira imagem, que foi a da cachoeira (Figura 10) percebemos o valor emocional para o Sr. Gilberto pois ela retrata uma paisagem anterior a vinculada profissionalmente, desvinculada da questão econômica.

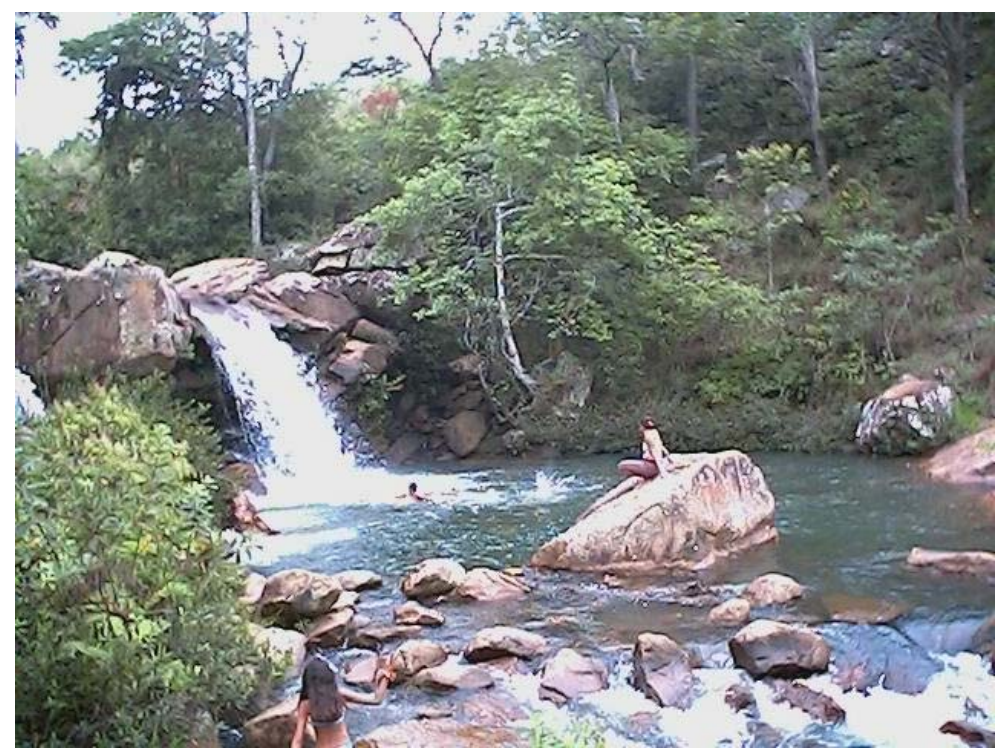

Figura 10. Imagem da Cachoeira do Águas Correntes. (Foto: I. V. Pimenta)

A a outra imagem foi a da nova rampa construída, segundo ele a maior da região com 50 metros de comprimento e que atrai muitos turistas (Figura 11), nesta imagem selecionada vemos que seu Gilberto agregou a esta imagem um valor financeiro, pois, segundo suas palavras, a rampa possui forte apelo comercial. Nesse caso essa imagem já vem carregada de uma forte influência do outro; o outro, turista, público alvo para o qual essa imagem foi pensada, foi construída. Essa 
imagem refletida, espelhada do interior do inconsciente do outro faz parte da estratégia de marketing do turismo.

A paisagem faz sentido a quem a olha, é como se ela pertencesse a quem a vê. E só o próprio indivíduo sabe que valor agregar a ela, pois depende de aspectos culturais, emocionais, sociais. A fotografia seria uma forma de ir além do estabelecido numa imagem de um folder ou de uma revista, até porque ao fotografar uma paisagem, geralmente, procuramos nos incluir nela, como se assim, ela nos pertencesse.

No folder, junto às imagens da cachoeira e das piscinas o clube se autointitula o "Paraíso das águas" (ver Anexo II), questionados sobre se o clube realmente corresponde a essa imagem de paraíso, alguns turistas, responderam o que está relatado a seguir:

A estudante Carla, define este clube como lindo, maravilhoso, realmente um paraíso.

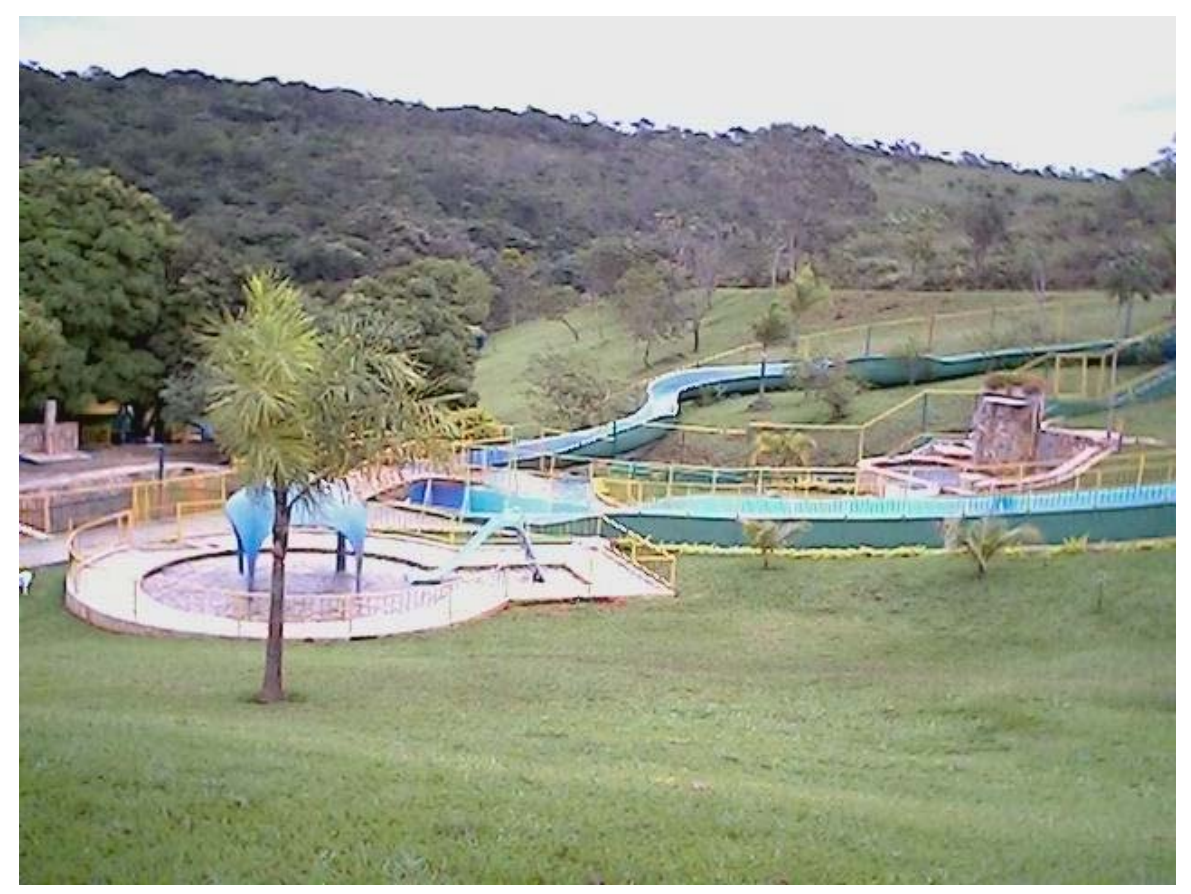

Figura 11. Imagem da Rampa e Toboágua. (Foto: I. V. Pimenta)

O dia, em que foi realizado este trabalho de pesquisa de campo, se apresentava com um céu nostalgicamente cinza, porém belo, mas nem por isso 
diminuia o ânimo e estado de graça dos visitantes, em meio a este panorama, encontramos um grupo de visitantes de Taguatinga que passava o dia no lugar, Madalena, se refere ao Águas Correntes, simplesmente como maravilhoso, muito bonito.

O agente administrativo William crê que seja quase um paraíso, necessitando ainda de algumas coisas para chegar a ser um.

Perguntou-se também sobre a questão dos resíduos:

O Sr. Gilberto diretor do clube pensa que para educar é preciso oferecer um ambiente limpo e asseado pois ele entende que o exemplo, deve partir do próprio estabelecimento. De fato, o espaço apresenta recipientes para os resíduos em toda a área do clube e o diretor relatou que o público corresponde às expectativas contribuindo e jogando seu lixo nestes depósitos.

Durante a visita ao local pudemos perceber que o grupo de turistas de Taguatinga descobriram o clube por parentes que vivem próximos ao local, destacaram como atrativos a limpeza, a infra-estrutura, o verde, a água e a paisagem porém reclamaram que havia poucas piscinas e estavam vazias. Ao fazer seu churrasco, procuraram manter junto a churrasqueira um depósito para depositar os resíduos. A preocupação com a preservação e conservação, foi percebido também nas placas informativas sobre a proibição de se fazer churrasco nas proximidades da cachoeira. Há também um letreiro que alerta para o uso de recipientes descartáveis por parte dos turistas. A preocupação deste estabelecimento em educar o público para a valorização do meio ambiente é vista com satisfação.

Procurou-se saber de alguns funcionários qual é sua percepção de paisagem, que paisagem gostariam de ver retratada numa fotografia.

O agente de portaria Antonio, natural do Piauí, trabalha no clube há um ano, disse que era a imagem dos turistas descendo na rampa a que mais gostava.

O agente de limpeza José Fernandes, um faz tudo no clube, gosta da imagem da mata.

Comentando as imagens selecionadas pelos entrevistados, percebemos que todos trazem internalizada uma imagem anterior na formação/composição da 
imagem de paraíso. No caso dos invivíduos simples essa paisagem está relacionada com a terra natal, com a família porém depois de um certo tempo trabalhando num empreendimento turístico, eles já passam a ser "contaminados" por uma paisagem profissionalmente construída. A partir do cruzamento de olhares (da paisagem interior e anterior desses trabalhadores e a paisagem do patrão), perdem a essência da paisagem "pura" inicial e passam a adotar uma imagem "negociada", incorporada do discurso da imagem da propaganda, do marketing.

$\mathrm{Na}$ pesquisa realizada nestes empreendimentos percebemos o quanto é importante corresponder à expectativa de paraíso que temos em nosso imaginário, pois o encantamento, o sonho das pessoas pode se transformar em frustração.

Cada vez mais os proprietários tentam fazer com que seu empreendimento corresponda a imagem de paraíso, seja construindo um novo equipamento turístico, melhorando a qualidade do atendimento, preservando o espaço natural ou adotando políticas de evolução ambiental.

Os valores para ter acesso a esses paraísos são altos, o que faz que o paraíso de cidadãos de classes menos privilegiadas fique somente no imaginário. 


\section{CONSIDERAÇÕES FINAIS}

A modo de encerramento deste trabalho, serão relacionadas algumas reflexões visando destacar alguns aspectos, que para efeito desta pesquisa, tornam-se importantes.

Deve-se ressaltar que a essência desse trabalho não está na atividade turística em si, e sim, nos fenômenos básicos que fazem com que essa atividade aconteça. Por isso a atividade turística não deveria iniciar sem uma prévia análise do fenõmeno "turismo", tais como:

$>$ análise do impacto ambiental

$>$ tratamento dos resíduos

$>$ orientação ambiental

$>$ conhecimento da flora e fauna que formadores do bioma

$>$ treinamento de pessoal, (principalmente no que diz respeito ao "olhar" sobre a paisagem, para que esses profissionais possam contribuir com imagens próprias na divulgação do empreendimento).

$\mathrm{Na}$ busca da redescoberta das paisagens do cerrado, um dos aspectos observados, é que quanto menor a formação acadêmica melhor é o conhecimento sobre a flora e fauna do cerrado, podemos afirmar que possuem mais apego e identidade com esta paisagem. No entanto, nem por isso, as outras pessoas com melhor formação e favorecimento social, deixam de admirar a beleza da paisagem do cerrado, embora não apresentem um conhecimento específico deste.

Por outro lado, nota-se um interesse na reconstrução e valorização da imagem cerrana, por diversos motivos, sejam estes por uma preocupação ambiental ou simplesmente pela necessidade de descobrir nesses diferentes componentes da paisagem, um lugar que pelo menos esteja próximo do ideal, quer dizer, que se uma 
aproxime do paraíso individual. Porém esta valorização precisa de pesquisas e investimentos que apontem para políticas de manejo ambiental sustentável, a fim de se manter o que resta do bioma cerrado, a fim que se garanta a preservação e sobrevivência da espécie.

Essa preservação passa pela educação do olhar do turista e do profissional de turismo para valorizar a paisagem cerrana. Paisagem é mais que a representação de belas imagens relacionadas ao paraíso, para que se agregue valor a ela e para que ela tenha significado deve-se mais que pronunciar as palavras e expressões da moda, como: preservação, conservação, ecologia, meio-ambiente, coleta seletiva do lixo, economia de água. Porém, tornando-se um ser consciente que estes recursos naturais que dão corpo a qualquer paisagem são importantes e necessárias. Enfim, devemos mudar o modo de perceber a paisagem e nos integrarmos a ela.

Quanto a percepção do paraíso foi percebido que busca-se encontrá-lo em cada imagem que é vista nas revistas, nos folders, nos catálogos de turismo e até mesmo na internet. Uma imagem de paraíso pessoal pode levar ao desejo de ir até ela através de uma bela imagem produzida e vendida como a paisagem do sonho. Certamente o que não se quer na relação paraíso pessoal versus propaganda turística, é que as expectativas sejam frustradas e que o paraíso prometido se transforme em pesadelo. E essa imagem de paraíso faz parte do discurso do mito cristão ocidental do Éden e o Brasil desde Pero Vaz de Caminha é referenciado na literatura como o verdadeiro paraíso materializado, observe:

De ponta a ponta é toda praia, muito chã e muito formosa. A terra, porém, em si, é muito bons ares assim frios e temperados (...) Águas são muitas e infindas. E em tal maneira é graciosa que querendo-a aproveitar, dar-se-á nela tudo por bem das águas que tem...

( Trecho da carta de Caminha)

O Brasil é sempre descrito como imenso jardim perfeito: a vegetação é luxuriante e bela (flores e frutos perenes), as feras são dóceis e amigas (em profusão inigualável), atemperatura é sempre amena ("nem muito frio, nem muito quente", repete toda a literatura e pero vaz de caminha), aqui reina a primavera eterna contra o "outono do mundo", o céu está perenemente estrelado, os mares são profundamente verdes, e as gentes vivem em estado de inocência, sem "esconder suas 
vergonhas" (diz Pero Vaz), sem lei nem rei, sem crença e pronta para a evangelização. Esses lugares-comuns literários possuem um sentido preciso que não escaparia a nenhum leitor dos séculos 16 e 17: são os sinais do Paraíso Terrestre reencontrado.

(CHAUÍ. Marilena. O mito fundador do Brasil. In: Sousa.2002.p 4)

O turismo em áreas rurais é uma alternativa eficiente à conservação e preservação da flora do cerrado. Faltam, porém, informação e orientação aos empreendedores, guias e turistas, pois este fato gera conseqüências como o fracasso do empreendimento, principalmente no que tange a questão da sustentabilidade da paisagem natural em que está inserido o turismo rural.

É necessário afirmar que este trabalho monográfico não tem a pretensão de esgotar a discussão relacionada com a paisagem do cerrado e a relação que esta tem com o turismo, mas fortalecer e suscitar esta abordagem nos mais diversos aspectos tratados.

Pelo fato deste trabalho ter sido extremamente gratificante seria interressante desenvolver estudos da imagem turística a partir do álbum de viagens e sua relação com o contexto língüístico, sendo uma alternativa de investigação o tema: "As palavras invisíveis nas paisagens do álbum fotográfico".

Preservar o meio ambiente não significa deixar de usar seus recursos, porém deve-se pensar em alternativas que conduzam à busca de novos olhares que contribuam e valorizem a paisagem nas suas diversas dimensões, com o intuito de proporcionar caminhos que orientem ao encontro do sonhado paraiso.

Para isto, faz-se necessário parcerias multidisciplinares, que envolvam orgãos públicos de fiscalização e controle, entidades particulares e instituições de pesquisa, com a finalidade de satisfazer, não apenas as necessidades econômicas, no tocante ao setor da indústria turística, mas que visem respeitar os aspectos sociais, culturais e os processos ecológicos essenciais, para que se garanta a diversidade biológica e de qualidade de vida. 


\section{REFERÊNCIAS BIBLIOGRÁFICAS}

AOUN,Sabáh. A procura do paraíso no universo do turismo, Campinas, SP:

Papirus, Vozes, 2001. (Coleção Turismo)

BARBOSA, Ycarim Melgaço. A Publicidade nos produtos turísticos. Ed. Aleph. (Série Turismo).

BITTENCOURT, José Neves. O espelho da "nossa" história: imaginário, pintura histórica e reprodução do século XIX brasileiro. Rev.TB. Rio de Janeiro, 1986.

FELFILI, Jeanine Maria;... [ et al.] Plantas da APA Gama e Cabeça de Veado: espécies, ecossistemas e recuperação / Brasília: Universidade de Brasília, Departamentode Engenharia Florestal, 2002.

MARESCA, Sylvain. O Fotográfico.in SAMAIN, Etiene (org.) Olhares Cruzados. Ensaio comparativo entre as abordagens fotográfica e etnográfiaca. São Paulo. Hucitec. 1998.

MARTINELLI, Marcelo. Cartografia do turismo e imaginário. In: RODRIGUES, Adyr Balastreri. Turismo rural. São Paulo: Contexto, 2001. pp.151-152. (Coleção Turismo Contexto).

NASCIMENTO, Itaboraí Velasco. Cerrado: O fogo como agente ecológico. Universidade Católica de Goiás - Vice-Reitoria de Pós-graduação e Pesquisa Instituto do trópico Subúmido. Goiânia - 2001.

NEVES, E.S. Paisagem - Conceito. Paisagem e Ambiente - São Paulo, FAUUSP, 1992.

PIRES, Paulo dos Santos. A Paisagem rural como recurso turístico. In: RODRIGUES, Adyr Balastreri. (Org.) Turismo rural. São Paulo: Contexto, 2001. (Coleção Turismo Contexto).

RODRIGUES, Adyr Balastreri. Turismo Rural no Brasil - ensaio de uma tipologia.

RUSCHMANN, Dóris van de M. O Turismo Rural e o Desenvolvimento Sustentável. In: Almeida, Joaquim Anécio; FROEHLICH, José Marcos; RIEDL, Mário (Orgs.) Turismo Rural e Desenvolvimento Sustentável. 2. ed. Campinas: Papirus, 2000. (Coleção Turismo). 
SALLES, Mary Mércia G. Turismo rural: Inventário turístico no meio rural. Campinas, SP: Editora Alíea, 2003.

SANTOS, Volnyr (coord). DELP - Dicionário Essencial da Língua Portuguesa. Porto Alegre, Editora Rigel, 2001.

SILVA, Graziano da Silva VILARINHO, Carlyle; DALE, Paul J. Turismo em áreas rurais: suas possibilidades e limitações no Brasil. In: Almeida, Joaquim Anécio;

SOUZA, Vilma de. Língua portuguesa e literatura brasileira: $1^{a}$ série ensino médio/ Vilma de Souza e Angela Maria da Silva Souto. _ Belo Horizonte: Editora Universidade, 2002. 136p. Coleção Pitágoras

FROEHLICH, José Marcos; RIEDL, Mário (Orgs.) Turismo Rural e Desenvolvimento Sustentável. 2. ed. Campinas: Papirus, 2000. (Coleção Turismo).

YÁZIGI, Eduardo. A Alma do lugar: turismo, planejamento e cotidiano em litorais e montanhas. São Paulo - Editora Contexto, 2001. 


\section{ANEXO I}
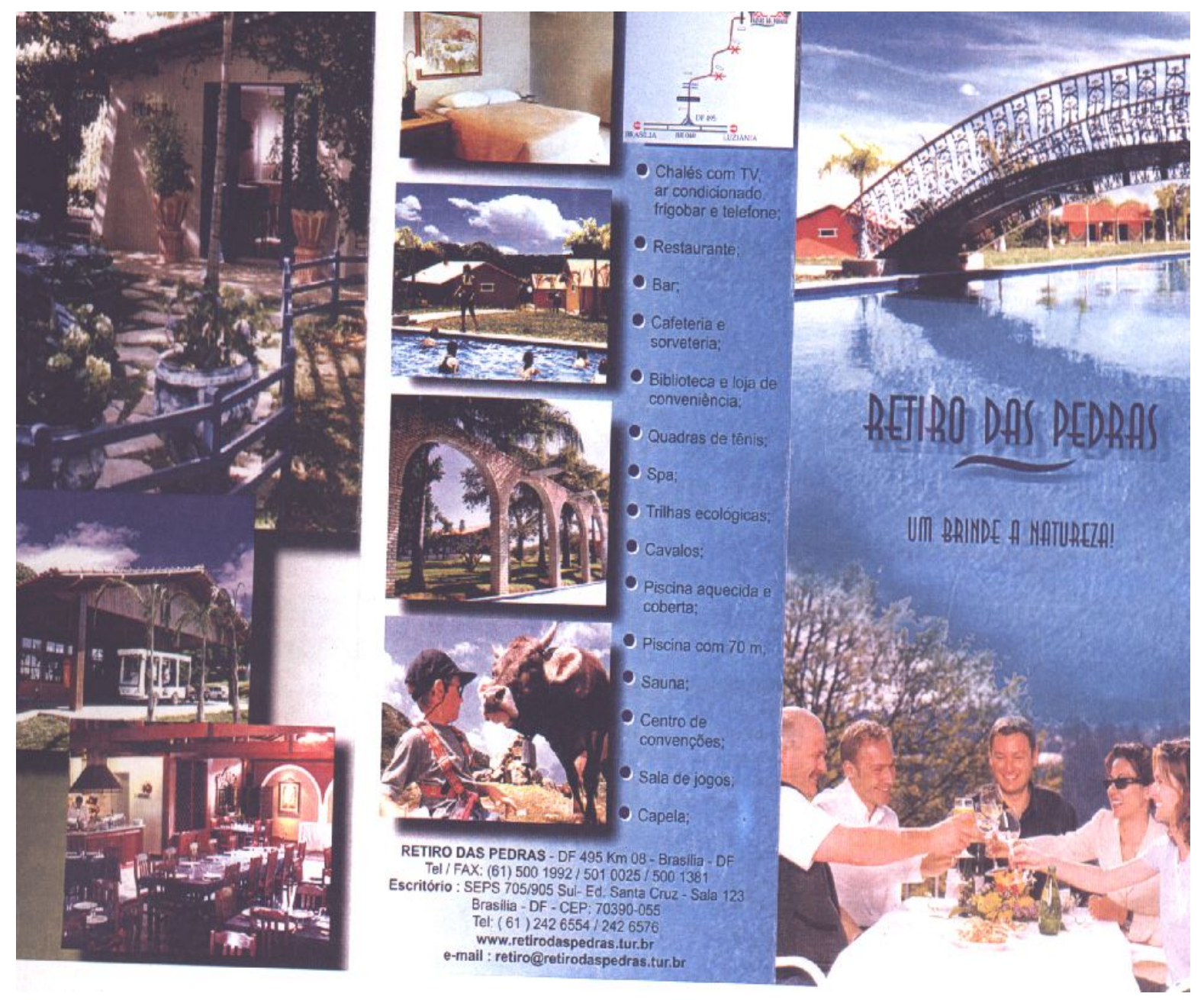

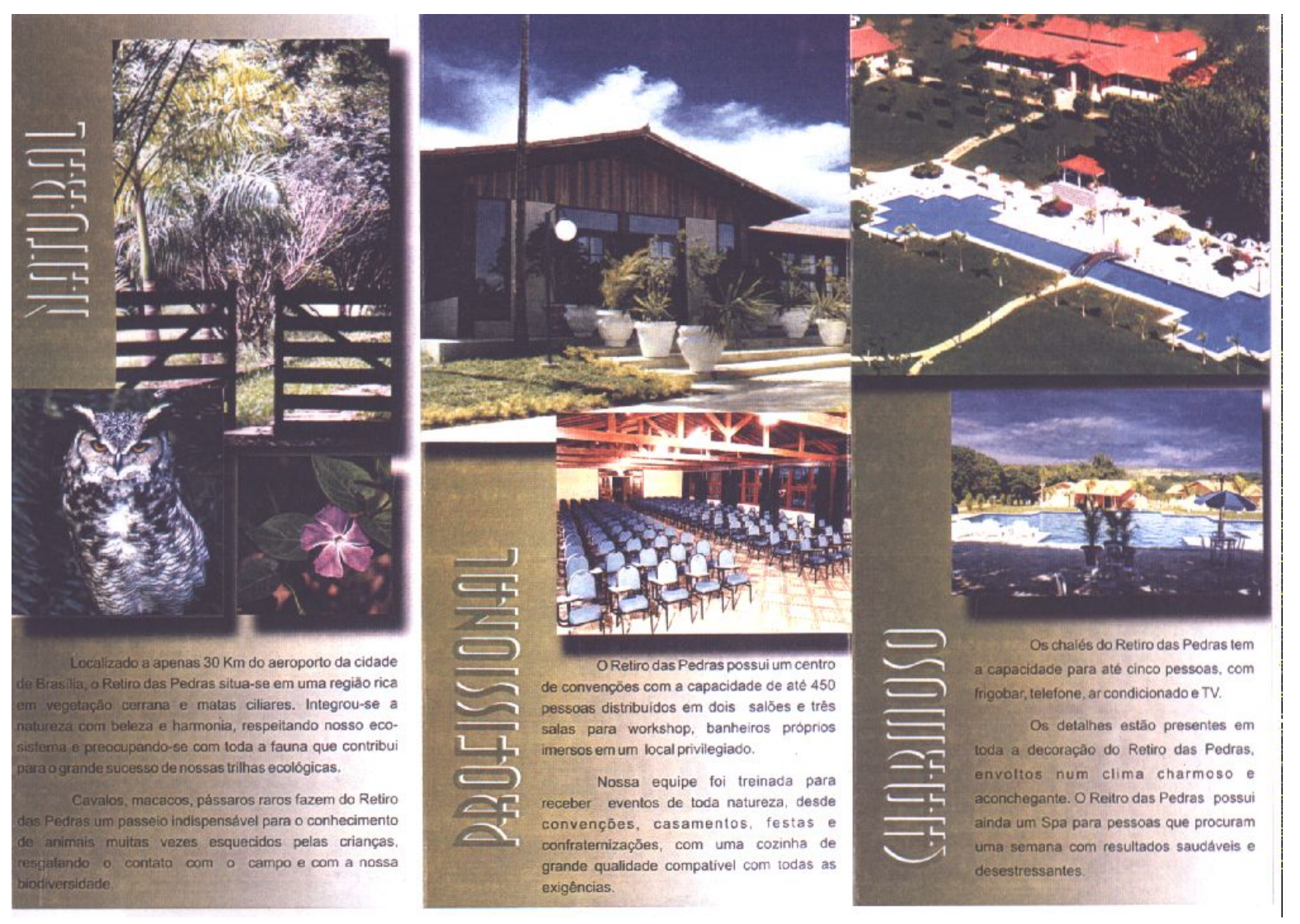


\section{ANEXO II}
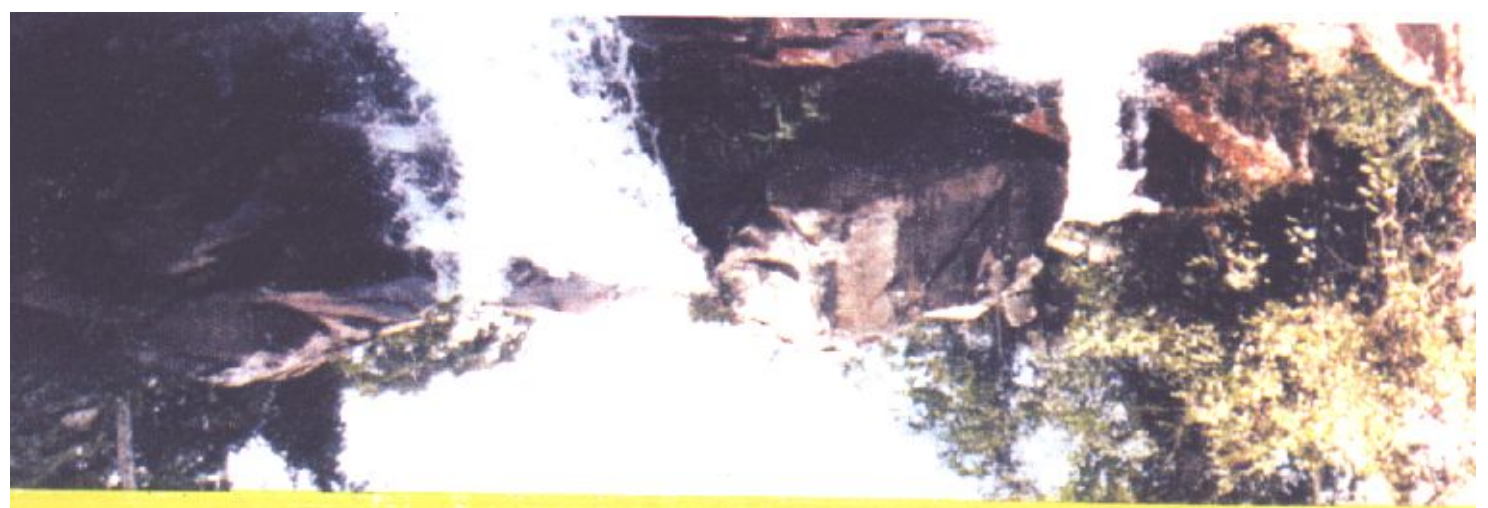

Como chegar às Águas Correntes? À $26 \mathrm{Km}$ do balão do aeroporto de Brasília, sentido Valparaízo Km 05, no monumento Solarius, faça o retorno a esquerda e entre a direita. Placas indicativas do Aguas Correntes the conduzirão ao Paraíso das Aguas. E não precisa ser sócio!!!
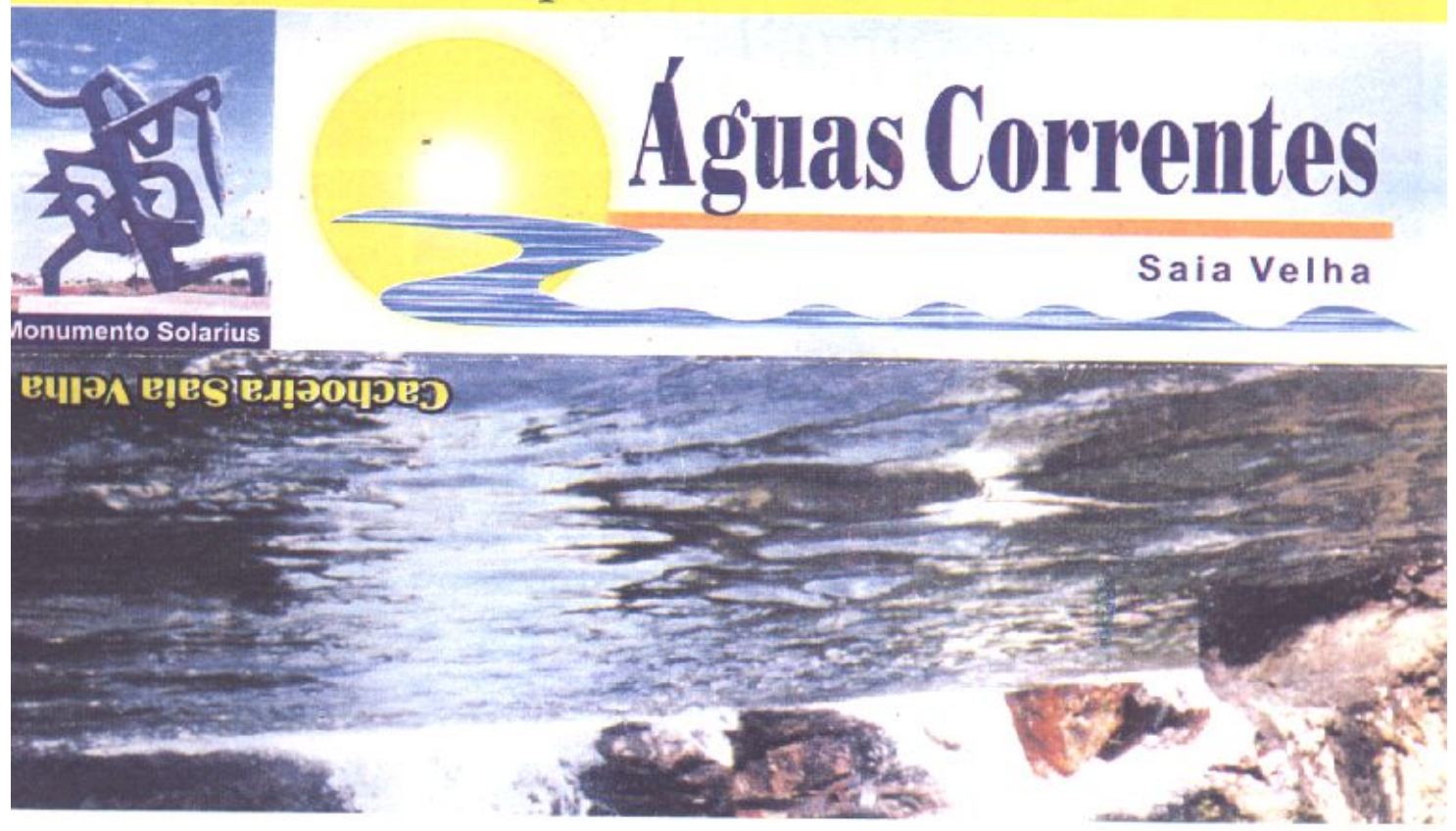


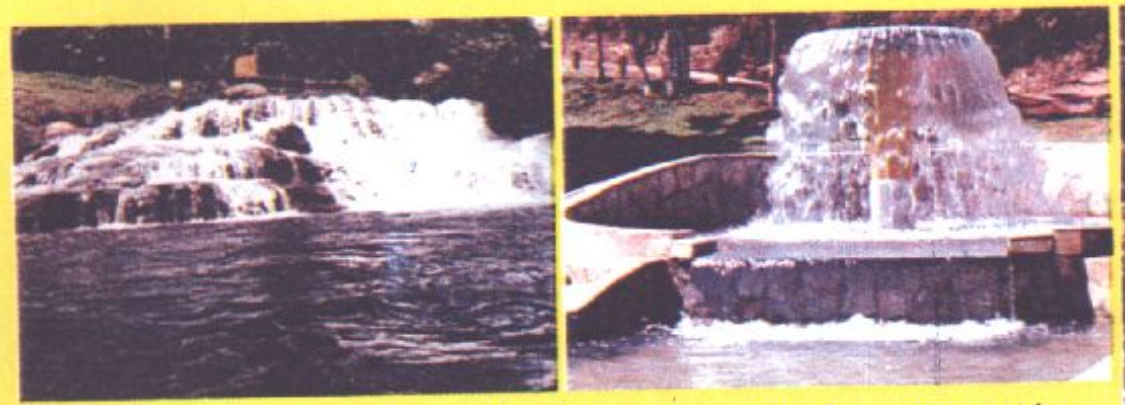

Natureza pura, atrações refrescantes, recompondo suas energias através de banhos em águas correntes e naturais.
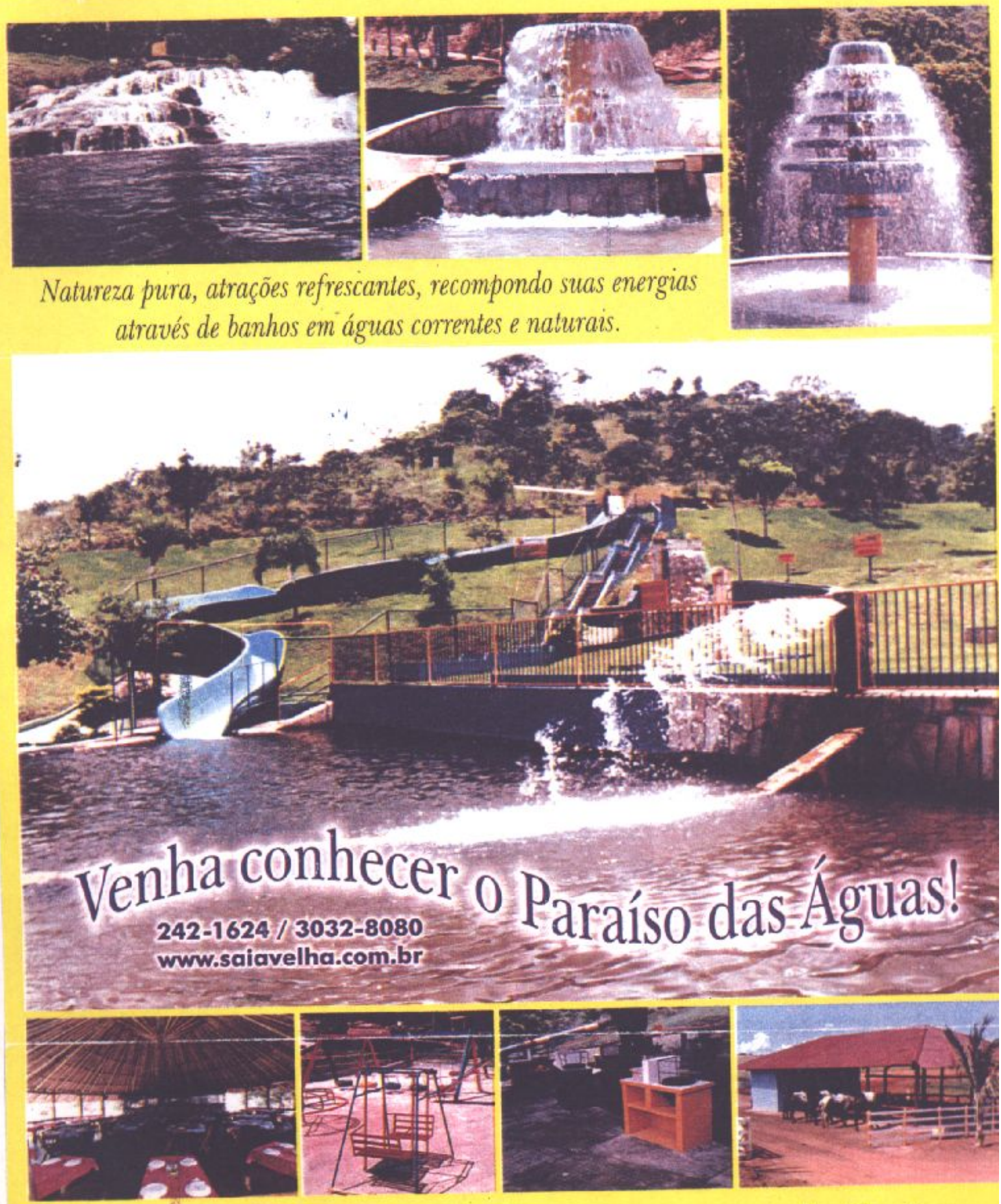

Restaurante, Playground, Churrasqueiras Individuais,

Passeios à Cavalo, Campos de Futebol, Sinuca, área para banhos de sol e muito mais!!! 